\title{
NETWORKS AND THE DYNAMIOS OF FIRMS' EXPORT PORTFOLIO
}

Juan de Lucio, Raul Minguez. Asier Minondo and rancisco Requena.

Documentos de Trabajo. N. 1513

\section{baneo gespaña}

\author{
Eurosistema
}


NETWORKS AND THE DYNAMICS OF FIRMS' EXPORT PORTFOLIO 
NETWORKS AND THE DYNAMICS OF FIRMS' EXPORT PORTFOLIO

\author{
Juan de Lucio
}

BANCO DE ESPAÑA

Raúl Mínguez

CÁMARA DE ESPAÑA

Asier Minondo

DEUSTO BUSINESS SCHOOL

Francisco Requena (*)

UNIVERSITY OF SHEFFIELD

$\left.{ }^{*}\right)$ We thank the anonymous referee for comments and suggestions to improve the final version of the paper. Our thanks also to Arne Hole, Juanjo Gibaja, Martin Rosvall, Laura Rovegno and participants at research seminars at the Inter-American Development Bank, University of Murcia, University of Sheffield, the World Bank and the Banco de España, and at the XVI Encuentro de Economía Aplicada in Granada, the XIV Congress in International Economics in Palma de Mallorca, the XV ETSG Conference in Birmingham and the XXXIX Congress of AECR in Reus. We also acknowledge financial support from the Spanish Ministry of Economy and Competitiveness (MINECO ECO2010-21643, ECO2011-27619 and ECO201346980-P, co-financed with FEDER), the Basque Government Department of Education, Language Policy and Culture (IT629-13) and the Generalitat Valenciana (project Prometeo/2011/098). We thank the World Bank for sharing with us the database on Mexican exporters.

${ }^{(*)}$ Corresponding author: Francisco Requena. Department of Economics, University of Sheffield, 9 Mappin Street, Sheffield S1 4DT UK. Tel: + 44114222 3398, Fax: + 44114222 3458. Email: f.requena@sheffield.ac.uk. 
The Working Paper Series seeks to disseminate original research in economics and finance. All papers have been anonymously refereed. By publishing these papers, the Banco de España aims to contribute to economic analysis and, in particular, to knowledge of the Spanish economy and its international environment.

The opinions and analyses in the Working Paper Series are the responsibility of the authors and, therefore, do not necessarily coincide with those of the Banco de España or the Eurosystem.

The Banco de España disseminates its main reports and most of its publications via the Internet at the following website: http://www.bde.es.

Reproduction for educational and non-commercial purposes is permitted provided that the source is acknowledged.

C BANCO DE ESPAÑA, Madrid, 2015

ISSN: 1579-8666 (on line) 


\section{Abstract}

We use network-analysis tools to identify communities in the web of exporters' destinations. Our network-based community measure is purely outcome-based; it captures multilateral rather than bilateral dependence across countries; and it can be calculated at the industry level. We next use our network-based community measure as a predictor of additional countries chosen by firms expanding their export destinations portfolios. Using data on new Mexican exporters, the probability of choosing a new export destination doubles if it belongs to the same community of any of the firm's previous destinations. The introduction of the network-based community variable improves the accuracy of the model by up to $19 \%$ relative to a model that only includes gravity variables. Industry-specific communities and general communities play similar roles in determining the dynamics of Mexican exporters' country portfolios.

Keywords: export market, network analysis, modularity, extended gravity, Mexico.

\section{JEL Classification: F1.}




\section{Resumen}

Utilizamos herramientas de análisis de redes para identificar las comunidades de países de destino de los exportadores. Nuestra medida de comunidad está basada en el resultado de decisiones reales, captura la dependencia multilateral entre países en lugar de la dependencia bilateral, y se puede calcular a escala sectorial. Usamos nuestra medida de comunidad basada en la red como predictor de los nuevos países elegidos por las empresas en expansión de su cartera de destinos de exportación. Utilizando datos sobre nuevos exportadores mexicanos, la probabilidad de elegir un nuevo destino de exportación se duplica si pertenece a la misma comunidad de cualquiera de los destinos anteriores de la empresa. La introducción de la variable comunidad basada en la red mejora la precisión del modelo, hasta un 19\%, con relación a un modelo que solo incluye variables de gravedad. Comunidades específicas de sectores y comunidades a escala agregada desempeñan un papel similar en la determinación de la dinámica de la cartera de países de los exportadores mexicanos.

Palabras clave: mercados de exportación, análisis de redes, modularidad, gravedad extendida, México.

\section{Códigos JEL: F1.}




\section{Introduction}

Recent access to micro-level trade data shows the protagonist role of adding new firms, products and destinations (the so-called extensive trade margin) in the long run growth of exports (Eaton et al., 2007; Bernard et al., 2009). Regarding new export destinations, Besedes and Prusa (2011) show that entry rates are higher for developing countries than for developed countries; however, these higher entry rates do not materialize in a higher export growth because the survival rates of export relationships with new destinations are much lower for developing countries than for developed ones. These facts motivate this paper: If destination path-dependence in exports exists, it is important that firms choose adequately export destinations because the chances of survival are higher and, by extension, export growth.

Until recently firm-level research in this area has mostly treated export status as a binary variable: firms are either exporting or they are not. Hence, empirical studies of entry into exporting have focused on the initial entry decision, particularly on identifying the firmspecific characteristics which set exporting firms apart from non-exporters, or on the determinants of the destination-product portfolio of an exporting firm. In this paper we focus our enquiry on a subsequent question: How do (new) exporting firms expand their destinations portfolio over time?

Exporters do not add new destinations to their portfolio at random. In fact, firms have a higher probability of adding destinations that are geographically, economically and culturally close to their domestic market and to other countries to which the firm has previously exported (Lawless, 2013; Morales et al, 2014; Defever et al, 2015). In this paper we propose to use tools of complex network analysis to measure how close trading partners are in the network. We implement a procedure that uses the strength of connections among countries in the network to generate clusters of countries ('communities'). In particular, we examine the network of destination countries of Mexican exporting firms in the year 2002. Using network tools (modularity), we find up to 10 different 'communities' for the entire network. We also find that the number and size of the communities change depending on the industry analyzed. Finally, we show that no gravity equation can be used to reproduce a counterfactual network with such a large number of clusters.

Next we use our network-based communities as determinants of the destinationsportfolio of new regular Mexican exporters over the period 2003-2009. We show that an exporter will have almost three times higher probability of choosing a new destination if it belongs to the same community of any of its previous destinations. The network variable keeps its strong impact even when we control for gravity-type variables, and improves the accuracy of the model up to $19 \%$. Finally we find that industry-specific destinationcommunities and general destination-communities have a similar influence on the evolution of Mexican firms' export-portfolio.

Our analysis is related to three different strands of literature that analyse firms' exports dynamics. First, our paper is related with the novel literature on the international-trade network, and in particular with those papers using gravity models with networks and a community-detection approach to identify communities in the World Trade Network (WTN). Kali and Reyes (2007) map the topology of international trade and develop new measures of 
economic integration based on network analysis. Fagiolo et al. (2009) and De Benedictis and Tajoli (2011) apply network analysis to describe the evolution of the WTN over the last 50 years. Dueñas and Fagiolo (2013) compare the topological properties of the actual WTN with the ones obtained from the web predicted by the gravity model. Reyes et al. (2014) and Barigozzi et al. (2011) explore have explored the community structure of the WTN at the aggregate level and at commodity level, respectively. We are the first to implement this methodology to analyze the country destinations network generated by exporters of one country, Mexico.

Second, our paper provides empirical support to the path-dependence hypothesis on export portfolio dynamics. Chaney (2011) proposes a model of international network formation where firms obtain information about new potential partners from their current trading partners. The network formation game yields equilibria where firms' export destinations are path-dependent. Albornoz et al. (2012) and Nguyen (2012) develop alternative multi-market export models based on the idea that a firm's foreign demands are uncertain and correlated across markets. When faced with multiple destinations to which they can export, many firms will choose to sequentially export in order to slowly learn more about its chances for success in untested markets. Experimentation becomes an optimal strategy leading to path-dependence in firms' export destinations. Our empirical findings support this argument for the case of Mexico since firms that become exporters have a higher probability to expand their export-portfolio within the same 'communities' of countries.

Third, our paper is related to the concept of "the geographic spread of trade", a term originally proposed by Evenett and Venables (2002). They showed that geographic and linguistic proximity to an existing export-market was a consistently significant factor in determining expansion into new markets for sector-level exports from developing countries, implying a role for learning from existing export experiences. Using firm-level export data, Lawless (2013), Morales et al. (2014) and Defever et al. (2015), for Ireland, Chile and China, respectively, explore the role of closeness to other destinations and show that firms tend to choose new export destinations that are geographically, culturally or economically closer to destinations that firms have been already exporting to. The first paper uses a survey of regular exporting in one year (so she cannot control for past export history); the other two papers use regular exporters so they have to address the challenging issue of past export history (state dependence). We solve that complication using a sample of new exporters since they have no past exporting history. In addition they examine particular industries (chemical and textile, respectively), while we cover all sectors.

The remainder of the paper is organized as follows. Section 2 presents the data and applies network analysis tools to identify communities within the web of Mexican exporters' destinations. Section 3 introduces the empirical model to examine how connectedness between countries affects the choice of new destinations by Mexican new exporters that expand their export portfolio. Section 4 presents the results of the empirical analyses. Section 5 concludes. 


\section{Communities in the network of Mexican export markets}

In this section, we present first the database used to perform our empirical analysis and then explore the web of export destinations in Mexico using tools from complex network analysis. Afterwards, we explain how to identify communities in a network and apply the identification algorithm of communities to the entire network of Mexican exporters. We also use a theorybased gravity equation to construct a counterfactual network in order to see if we can reproduce the same communities that we observed in the actual network. Finally, we construct sector-specific networks and implement the algorithm of identification of communities separately to each of them and show that the number of communities and its members vary substantially from sector to sector. We use again the gravity equation to construct counterfactual industry-specific networks in order to check if we can reproduce the same sector-specific communities that we observed in the actual network.

\subsection{An exploration of the web of export destinations}

For our empirical research, we use the transaction level customs data on the universe of Mexican exporters over the period 2000-2009. The database was facilitated by the World Bank's Trade and Integration Team (Cebeci et al., 2012). ${ }^{1}$ The database provides the annual value of exports per firm, destination and Harmonized System 6-digit product code. ${ }^{2}$ We use data over the period 2003-2009 to analyze the dynamics of exporters' destination portfolio in the next section (our dependent variable in the econometric exercise) and data over the period 2000-2002 to examine the network of export markets and construct the community measure in this section (our main explanatory variable). A detailed description of the Mexican firm-level data as well as other data sources used in the paper can be found in the Data Appendix section and in Tables A1 and A2 in the Appendix.

We begin our empirical analysis by examining the network of Mexican firms' export destinations using tools from network analysis. Figure 1 presents the network of Mexican exporters' destinations in year 2002. ${ }^{3}$ Export destinations are nodes in the web and two nodes are connected by an edge if there is at least a firm that exports to both nodes. The size of the node is correlated with the number of firms that export to that destination and the size of the edge (weight) is correlated with the number of firms that export to both destinations linked by the edge. The figure only includes the top 65 destinations of Mexican exporters, which represent $79 \%$ of Mexican exports. ${ }^{4}$ The most important destinations for Mexican exporters were the US (25,730 firms), Guatemala (2,534 firms), Canada (1,931 firms), Costa Rica (1,855 firms) and El Salvador (1,394 firms). All the nodes are connected in the network and, hence, each node has a degree of 64 . The edges with the highest weights were Canada-US with 1,534 firms exporting to both destinations, Guatemala-US with 1,368 firms, Costa Rica-US with 1,084 firms, Costa Rica-Guatemala with 923 firms and Colombia-US with 913 firms.

\footnotetext{
1. Data were collected by the Trade and Integration Unit of the World Bank Research Department as part of their efforts to build the Exporter Dynamics Database (http://econ.worldbank.org/exporter-dynamics-database).

2. For example, one record of our database is the annual value of exports of "Pullovers, cardigans etc. of wool or hair, knit" (HS-6 code 6110101) by a Mexican exporting firm (identifier 15) to Italy in 2002.

3. In the robustness section we also use the 2000 and 2001 data to construct the network of Mexican firms' export destinations.

4. A country is included in the network if at least five firms were exporting to the country.
} 


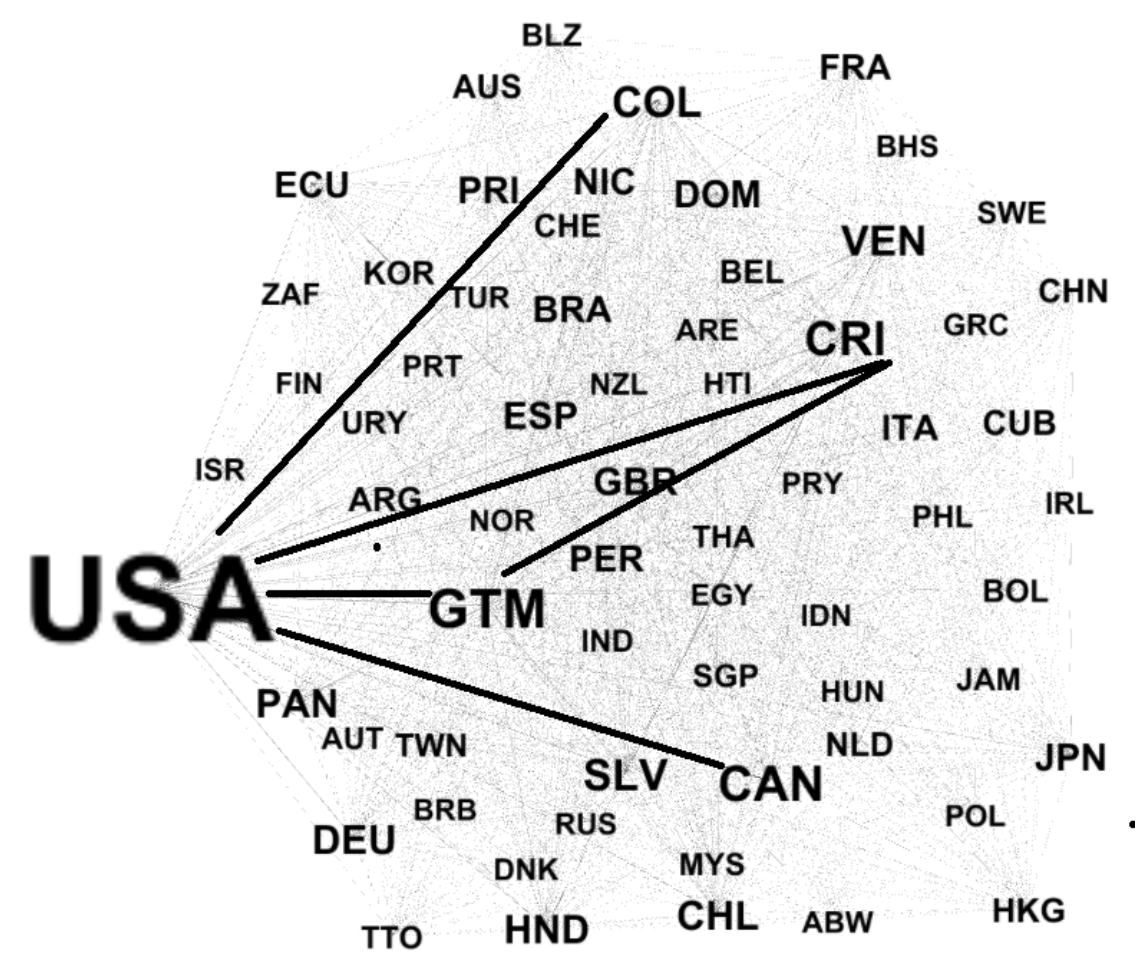

\subsection{Identification of communities}

In the network of countries where Mexican firms export to, we want to identify communities of countries that have stronger connections among them than with the rest of destinations in the network. These tighter relationships reveal that if a firm exports to one country in the community it will also tend to export to other countries within the community. One widely used procedure to identify communities within a network is the maximization of a modularity function (Newman, 2006), which is expressed as follows:

$$
\mathrm{Q}=\frac{1}{2 \mathrm{~m}} \sum_{\mathrm{ij}}\left[\mathrm{A}_{\mathrm{ij}}-\frac{\mathrm{k}_{\mathrm{i}} \mathrm{k}_{\mathrm{j}}}{2 \mathrm{~m}}\right] \delta\left(\mathrm{c}_{\mathrm{i}}, \mathrm{c}_{\mathrm{j}}\right)
$$

where $Q$ is the modularity index, $m$ is the number of edges in the network, $A_{i j}$ is the number of edges between node $i$ and node $j, k_{i}$ and $k_{j}$ are the degree of nodes $i$ and $j$, respectively, and $\delta\left(C_{i}, C_{j}\right)$ is a delta function that takes the value of 1 if $i$ and $j$ belong to the same community, and zero otherwise. ${ }^{5}$ The term in brackets compares the number of edges between two destinations with the number of edges we would expect if edges were distributed randomly in the network, providing that the degree of each destination is not altered. Hence, the term in brackets compares the actual number of relationships with a benchmark number of relationships. If the number of edges between $i$ and $j$ is higher than the benchmark, these destinations will form a community. The network will be partitioned in a number of communities that maximizes the value of $Q$.

The procedure to determine the optimum number of communities is not trivial, as the number of possible combinations of destinations rises exponentially with the number of destinations, making the exhaustive comparison of all possibilities unfeasible. To overcome this problem, different algorithms have been proposed to maximize modularity and identify

5. Reyes et al. (2014) implement the same algorithm in the detection of communities in the World Trade Network (WTN). 
communities within a network. In this paper, we use the algorithm proposed by Blondel et al. (2008). However, as pointed out by Fortunato and Berthelemy (2007), the modularity maximization algorithm has a resolution-limit limitation, as it might aggregate small communities within a broader community. In order to resolve this limitation they suggest applying the maximization algorithm iteratively. First, the algorithm is applied on the whole network. Second, the algorithm is applied only on each community identified in the first step. The process stops once the algorithm does not find any further partition. In each step, it should be checked that the number of edges within the communities identified by the algorithm is larger than the expected number of edges. This iterative process has the advantage of identifying hierarchies of communities. At the beginning, the algorithm identifies few communities, characterized by a large number of members with only just above the average connections between them. However, with each iteration, large communities are fragmented into smaller communities characterized by stronger ties among their members. To avoid a too long iterative process and awkward relationships, we run the community detection algorithm on the sample of destinations included in Figure 1.

Figure 2 displays the process of community-identification in Mexico. In the first iteration, the algorithm identifies two big communities. The first community is composed by countries located in the American continent, except USA and Canada; and the second community by the rest of countries. When we apply the algorithm on the community of countries located in the American continent, three final communities (shaded in yellow) emerge. The first community is formed by South American countries: Argentina, Bolivia, Chile, Colombia, Ecuador, Paraguay, Peru, Uruguay and Venezuela. The second community is formed by Central American countries and three Caribbean countries: Belize, Costa Rica, Cuba, Dominican Republic, El Salvador, Guatemala, Honduras, Nicaragua, Panama and Puerto Rico. The third community is formed by Caribbean countries: Bahamas, Barbados, Haiti, Jamaica and Trinidad and Tobago. When we apply again the modularity maximization algorithm on the rest of countries community we get a fourth final community composed by large developed countries: Canada, France, Germany, Great Britain, Italy, Spain and USA. If we further iterate the group of remaining countries we end up with six additional final communities. The fifth group is composed by small European countries: Austria, Belgium, Denmark, Finland, Netherlands, Norway, Sweden and Switzerland. The sixth community only includes three large Asian countries: India, Indonesia and Turkey. The seventh community encompasses countries located in or near the Middle-East area: Egypt, Israel, Saudi Arabia and United Arab Emirates, and two peripheral European Union countries: Portugal and Greece. The eighth community is composed by two Eastern European countries: Poland and Russia. The ninth community is formed mostly by Asian countries: China, Hong-Kong, Japan, Korea, Malaysia, Philippines, Singapore, Taiwan and Thailand; countries located in Oceania: Australia and New Zealand; and two emerging countries: Brazil and South Africa. The final community is formed by two small European Union countries: Hungary and Ireland. 


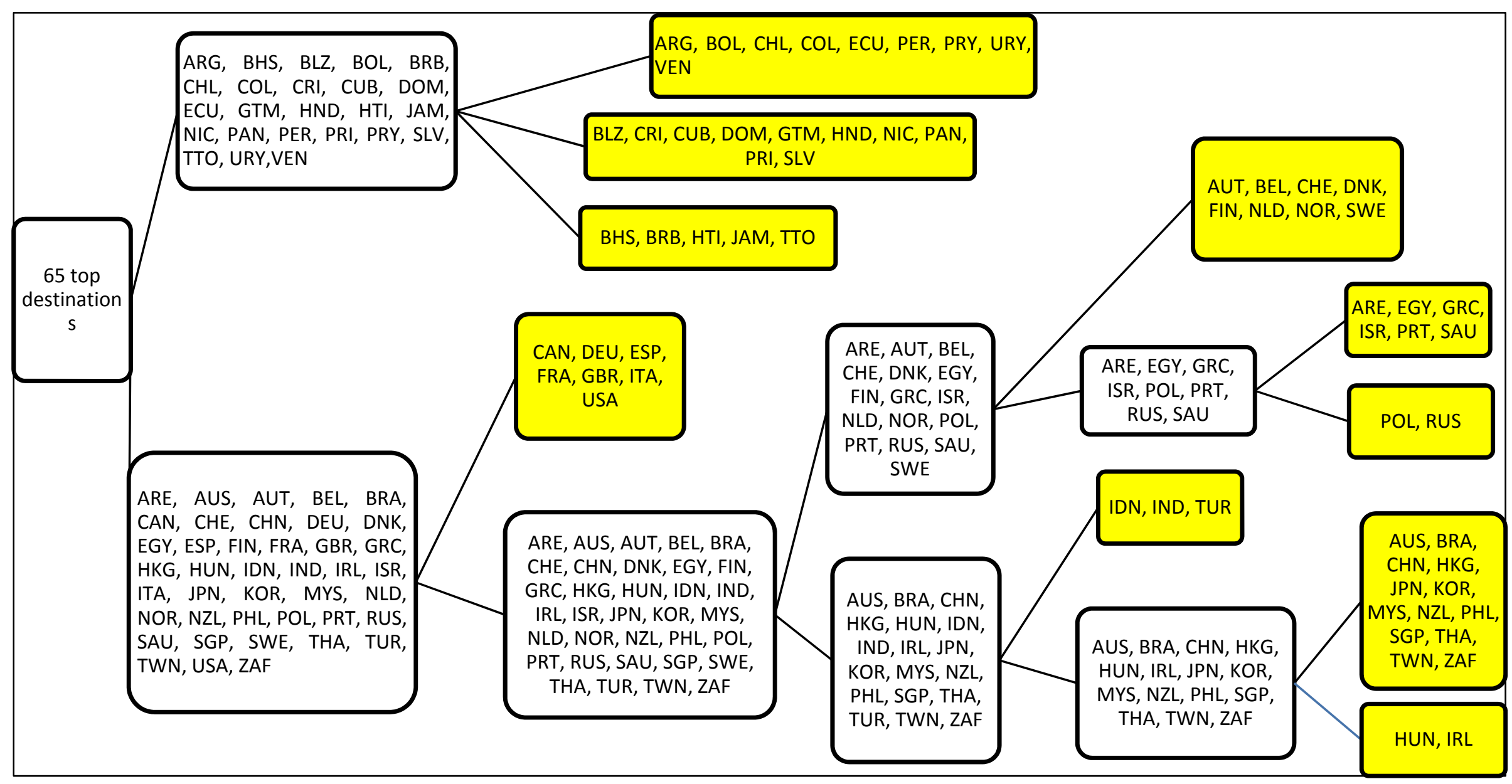


We can observe that gravity variables, such as geographical location, play a role in the formation of communities. For example, most of South American countries are located in the same community and most of Central American countries are located in the same community. However, we also observe that there are some countries that do not obey the geographical rule. For example, Brazil does not belong to the community of South American countries, but rather to a heterogeneous group that encompasses distant and emerging countries. We also observe that Canada and the US do not form a North American community, but are integrated in a broader large high-income countries' community. These cases point out that there might be other reasons besides those captured by observable gravity variables that might explain how (geographically, culturally and economically) close countries are to each other. As the network of Mexican export-destinations is built upon the choices taken by Mexican exporters, each community identified in the network acts as a synthetic indicator of all the variables that affect the degree of closeness among export destinations.

Next, we want to check whether a theory-based gravity model is capable to generate a network with our data such that the number and composition of countries in each community resemble the ones we have obtained using the raw data. We follow Reyes et al. (2014) in order to analyse the degree of similarity between communities identified by the modularity-function using raw network data and using predicted network data obtained from the gravity model. More specifically, we use the Adjusted Rand index - RAND - (Rand, 1971) and the Variation of Information index - VI - (Meila, 2003) to measure similarity between clusters (i.e. communities).

We first estimate an augmented gravity equation where the dependent variable is the number of Mexican firms in 2002 that exported simultaneously to a pair of destinations and the explanatory variables include the (log) product of GDP or country pairs, (log) bilateral distance, (dummy) common border, (dummy) common language and (dummy) common regional trade agreement membership. To account for multilateral resistance terms we also include country-origin and country-destination fixed effects. Our network has 65 nodes (countries) so the total number of country pairs is $2080\left(65^{\star} 64 / 2\right)$. The results of the estimation by Pseudo-Poisson Maximum Likelihood (PPML) are displayed in the first column of Table A3 in the Appendix. As we expected, the number of Mexican firms that export simultaneously to two destinations in 2002 is positively correlated with economic size and negatively correlated with the distance between destinations. In addition, sharing a common language also increases the number of exporting firms. Having a common colonizer or being member of the same regional trade agreement have no significant impact on the number of firms. Finally, sharing a common border has a significant negative impact on the total number of Mexican firms that export simultaneously to these destinations.

Next, we obtain the predicted number of firms exporting simultaneously between nodes to generate a counterfactual trade network of Mexican exporters and apply the modularity algorithm to detect communities. Table A4 in the Appendix shows the results. For the whole sample (first row), we identify 10 communities using the raw data (Figure 2). The number is reduced to only 4 communities when we use the network predicted by the gravity model. In addition, the low values of RAND (0.175) and the high values of $\mathrm{VI}(1.57)$ reveal that the distribution of countries across communities is very different using the real network and the predictions of the gravity model. Our results show that a theory-based gravity model does not generate the communities identified from raw data. The reason is that the gravity model is 
unable to replicate the "richness" of multilateral relationships between countries in the destinations network created by Mexican exporting firms. ${ }^{6}$

\subsection{Sector-specific communities}

One of the key advantages of our approach is that it can be easily implemented to identify network-based communities at the industry level. It might be the case that countries belong to the same community in one industry but to a different community in another industry. For example, in the case of Mexico and regarding tequila, Country A and Country B might form a community because both countries have the same regulations on the maximum alcohol content. In this case, the tequila that has been modified to meet the requirements in Country A will also be suitable for Country B, leading these two countries to form a community. In contrast, for book sales, Country A and Country B might belong to different communities because they speak different languages. Extended gravity measures cannot fully capture these differences because geographical and cultural variables do not usually vary across industries.

To capture this possibility, we classify exporters in one of seven broad-defined sectors: agriculture, chemicals, machinery \& transport equipment, metals, non-metallic minerals, paper and textiles. For each sector, we identify the sector-specific destinationcommunities and the rest of industries destination-communities. The limitation of this analysis is that the number of destinations at the industry level is smaller than at the aggregate level. To keep a sufficient amount of destinations we set a less stringent criterion to determine the sample used to identify communities. In particular, we only exclude from the sample those destinations that are served only by one exporter. The sample that meets this requirement and is common for the seven sectors is formed by 55 destinations. They represent $69 \%$ of Mexican exports in 2002. To identify the communities we follow the same procedure as the one used to identify communities in the whole network.

Table A5 in the Appendix displays the identified communities in each of the seven sectors in Mexico. We should stress that results should be taken cautiously as we use highly aggregated sectors and few firms might be linking some marginal destinations, leading to firm-specific communities. As shown in the table, there are differences in the number of communities among sectors as well as in the mix of countries in each community. The highest number of communities is found in chemicals, 10, and the lowest in paper, 8 . We observe that there are some broad communities present in most sectors, such as a cluster of South American countries, a cluster for Central American countries and a cluster for Caribbean countries. However, the size of these clusters and its members vary from sector to sector. Moreover, in some cases, the communities of South American and Central American countries are merged. Finally, Asian countries, large and high-income developed countries, and smaller and high-income European countries tend to stay in the same community, with less variation than other groups of countries across industries.

6. What other factors do 'community' capture that observable standard gravity measures do not? First, it might capture similarities related to consumer preferences (Linder, 1961). For example, for a Mexican exporter of beer, two countries might belong to the same community if consumers in both countries have a preference for low alcohol-content beers. Once the Mexican exporter incurs in the fixed cost of adapting its beer to a lower alcohol content to enter the first country, it will face lower cost to enter the second market. Hence, the exporter will tend to export to both markets. Second, similarities might also stem from regulation. For example, if a Mexican exporter of avocados incurs into a fixed cost to meet the phytosanitary regulations of a country (e.g. getting a certain quality-label), it will have lower costs to enter other markets sharing similar phytosanitary measures. Third, similarities might arise due to common distribution networks. For example, if a Mexican exporter selects a distributor for its products in a market, it will face lower cost to enter the markets in which this distributor is also present. 
To assess the similarity among communities across sectors we calculate an adjusted RAND index. This index, ranging between 0 and 1 , calculates the fraction of destination pairs that belong to the same community in two different sectors. ${ }^{7}$ As shown in Table A6 of the Appendix, the adjusted RAND indexes lie between 0.16 and 0.41 . In most cases the correlation across partitions is weak, confirming that destinations tend to belong to different communities when examining different industries. In the last column of Table A6 in the Appendix, we calculate the adjusted RAND index for the sector partitions and the rest of sector partitions for each sector. We observe a weak correlation between partitions, ranging from 0.14 to 0.36 . These results point out that the communities identified at the industry-level are different to those identified for the whole set of exporters.

Finally, we check whether a theory-based gravity model is capable to reproduce the original network so the number and composition of the communities is similar to the ones obtained from the modularity algorithm applied to the raw data. Repeating the same steps of the previous subsection, results of the gravity estimations sector-by-sector are displayed in column 2-8 in Table A3 in the Appendix while the similarity measures between clusters across sectors are displayed in row 2-8 in Table A4 in the Appendix. There are large differences in the number and composition of sector-specific communities. The number of communities using the raw data is always larger than the ones obtained from the predicted network using a gravity model. In addition, the values of RAND index tend to be small (ranging from 0.002 to 0.262 ) and the values of $\mathrm{VI}$ index tend to be far from zero (ranging from 1.504 to 2.635). We conclude that a theory-based gravity model is not able to generate a network such that the communities identified using the modularity algorithm resemble those obtained from raw data. Again, the reason behind this finding is that the gravity model does not satisfactorily capture all the multilateral relationships between countries in the network of Mexican firms' export destinations.

7. Specifically, the index calculates the fraction of correctly classified (respectively misclassified) elements to all elements. The index is adjusted to ensure that the expected value of the index for two random partitions is zero (Hubert and Arabie, 1985). 
So far we have calculated network-based communities from the entire web and industryspecific webs of Mexican firms' export destination portfolio in year 2002. The rest of the paper investigates whether our network-based communities helps to predict which countries will be chosen by new exporting Mexican firms that expand their destination portfolio after start exporting in 2003. We begin by explaining the empirical model used to study the determinants of the expansion of destination portfolio by exporting firms. Next we describe sample of firms used to perform the empirical analysis.

\subsection{Empirical model and econometric specification}

Let $\boldsymbol{y}_{i G t}=\left(y_{i t t}, y_{i 2 t}, \ldots, y_{i k t}\right)$ denote the vector of an exporting firm i's current destination portfolio $G$ made of $K$ countries. We want to examine the decision about where to export when a firm expands the portfolio of destinations $G$. If destinations share common characteristics, having served one destination might reduce the sunk cost of entering similar destinations. Hence, previous export destinations might determine the export-path. Our interest lies in the quantification of the effect of "similarity" between countries on the probability of entering a new export destination. In particular we want to examine two types of measures: those based on gravity-type indicators and those based on our network analysis.

We derive our econometric equation from a simple model of export participation into specific foreign markets by profit-maximizing firms that produce one good in the local market and sell part of the production abroad. There are several alternative markets and firms have to decide which markets to export to. At any period, exporting firms have the choice of entering into a number of markets if it did not export to those markets in the previous period. Let $\pi_{g t}$ be firm i's profits from exporting to market $g$ in year $t$. We assume that the expected profits of exporting to country $g$ by firm $i$ is a linear function of factors affecting the destination choice,

$\pi_{i g t}=\boldsymbol{I}_{-g, t-1}^{\prime} \alpha+\boldsymbol{\theta}_{g}+\varepsilon_{i g t}$

where the vector $\mathrm{I}_{-\mathrm{g}, \mathrm{t}-1}$ includes variables that measure the "mass" of information that firm $i$ might obtain from previous exporting experience in other destinations, $\theta_{g}$ is a vector of destination-specific constant terms and $\varepsilon_{\mathrm{ig}}$ is a random term denoting the unobservable (by the researcher) unique profit advantage to the firm $i$ from selling in country $g$.

An exporting firm will choose to export to a particular country if she earns the highest possible profit. Formally, the gth country is chosen by firm $i$ as a new export destination (omitting the subscript $t$ ) if $\pi_{\mathrm{ig}}=\max \left(\pi_{\mathrm{ik}}, \mathrm{k}=1 \ldots \mathrm{K}\right)$. If the firm-specific random terms are independently distributed, each with a Type I extreme value distribution, McFadden (1974) showed that the probability of a firm $i$ to choose to export to destination $g$ compared to the probability to choose other destination $k$ is

$P_{i g}=\operatorname{Pr}\left(\Pi_{\mathrm{ig}}>\Pi_{\mathrm{ik}}, \mathrm{g} \neq \mathrm{k}\right)=\frac{\exp \left(\mathrm{I}_{\left.\mathrm{g} t-1^{\prime} \alpha+\theta_{g}\right)}\right.}{\sum_{k} \exp \left(\mathrm{I}_{\mathrm{g} t-1^{\prime}} \alpha+\theta_{k}\right)}$

The estimates are obtained by maximizing the likelihood function, $L=\prod_{i} \prod_{g} \mathrm{P}_{\mathrm{ig}}$. The model described above is known as conditional logit model (CLM). Since firms may choose more than one destination in a particular year, we need to decide how to handle the issue of 
simultaneous multiple choices. ${ }^{8}$ There are two possible strategies: (1) we assume that destination choices are independent within the firm when two or more destinations are chosen or (2) we restrict the sample to those firms that choose only one destination to expand their destination portfolio. We have implemented both strategies to see whether our results are sensitive to the sample choice. ${ }^{9}$

We create three sets of variables that capture the "mass" of information about destination $g$ that firms obtained from previous exporting experience $\left(\mathrm{I}_{-\mathbf{g}, \mathbf{t}-\mathbf{1}}\right)$. First, we use our network-based community variable, $\mathrm{I}_{-\mathrm{g}, \mathrm{t}-1}^{\text {commity }}$. This variable takes the value of one if the new export market belongs to the same community of any of the firm's previous destinations and zero otherwise. ${ }^{10}$

Second, we include extended gravity variables to control for physical distance, border, geographical region, language, migration, regional trade agreement and income per capita level between a new destination and the past destinations in the portfolio of the Mexican firm. Then the variable $I_{-g, t-1}^{\text {distance }}$ characterizes the countries' geographical distance relationship to prior export destinations of the firm. It takes the value of one if the new export destination capital city is less than a certain number of kilometers away from the capital city of any of the previous destinations and zero otherwise. In the benchmark analysis, we use a $1,500 \mathrm{~km}$. radius. We also proxy for the geographical links between countries using a common border dummy variable, $I_{-g, t-1}^{\text {border }}$, which takes the value of one if the new export destination shares a land-border with any previous destination and zero otherwise; and $I_{-g, t-1}^{\text {region }}$, which takes the value of one if the new export destination is in the same geographic region of any of the previous destinations and zero otherwise. ${ }^{11}$ The regional dummy variable also controls for the existence of natural trade blocs in international trade (Frankel et al., 1995). We also consider cultural closeness measures such as common language between export destinations. Specifically, the variable $I_{-g, t-1}^{\text {language }}$ takes the value of one if the new export destination speaks the same language of any of the previous destinations and zero otherwise. We also proxy for economic proximity, controlling the presence of any previous export destination located in the same income quintile of the new export market. We also consider other variables that might enhance the proximity between destinations, such as migration flows and belonging to the same regional trade agreement. Specifically, the variable $I_{-g, t-1}^{m i g r}$ takes the value of one if any previous destination has at least 100 immigrants and 100 emigrants in the new export destination and zero otherwise. The variable $I_{-g, t-1}^{r t a}$ takes the value of one if the new export destination belongs to the same regional trade agreement of any of the previous destinations and zero otherwise.

Finally, when we do not include country-specific dummies $\left(\theta_{g}\right)$ in Equation (2), we include a set of gravity variables in order to control for observable closeness between the

8. Notice that many firms in our sample expand their portfolio in various consecutive years but we are treating each year independently. Sequential exporting is becoming an important topic (Albornoz et al., 2012) and some econometric improvements are addressing that issue (Morales et al., 2014).

9. Notice that CLM does not allow the inclusion of explanatory variables that are not directly related to the choices. In our case, it means that we cannot estimate a single parameter to capture the impact of firm-specific characteristics on the firm's probability of exporting to a particular destination. Another potential limitation of CLM is the risk of violation of the Independence Irrelevant Alternatives (IIA) assumption. In the sensitivity analyses section we also estimate equation (3) with nested logit that relaxes the IIA assumption. Finally we also estimate a mixed logit model, which allows taking into account whether destination choices are somehow related by imposing that the random coefficients are the same across choices taken by the same firm. We use Stata $\mathrm{v} 13$ in our regression analysis.

10. Notice that we constructed our "stock" community variable with 2002 data, before new exporters start expanding their "flow" of destinations since 2004 onwards.

11. We use the seven major regions identified by the World Bank: East Asia \& Polynesia, Europe \& Central Asia, LatinAmerican \& Caribbean, Middle East \& North Africa, South Asia, and Sub-Saharan Africa. 
domestic market (Mexico) and each new export market: the geodesic distance between Mexico and the new export market, a dummy that takes value of one if the destination shares a land border with Mexico, a dummy that takes value of one if the official language in destination is Spanish; a dummy that takes value of one if the destination has a free trade agreement with Mexico (USA, Canada, EU countries, Bolivia, Costa Rica and Nicaragua); and, a dummy that takes a value of 1 when there are more than 250 migrants from each country living in the other country. We also include GDP as a proxy for the attractiveness of the new export market. Table A8 in the Appendix provides the summary statistics of the gravity-type explanatory variables used in the regression analysis.

\subsection{Data: the dependent variable}

Our sample consists of all $(6,026)$ Mexican exporting firms that internationalized between 2003 and 2007 and carried on exporting until 2009. We called these firms "new regular exporters". ${ }^{2}$ There are some interesting features that explain why we have chosen them. First, we know their entire export portfolio since we know when they started exporting. Second, they account for a significant share of Mexican exports (21\% of total firms, $23 \%$ of all transactions and $21 \%$ of all value of exports in 2009). Third, they exhibit dynamics of export destination portfolio (entry and exit) similar to the old regular exporters (see Table A2 in the Appendix).

TABLE 1. Dependent variable. Number of new export destinations per firm-year

\begin{tabular}{|c|c|c|c|c|}
\hline \multirow[b]{2}{*}{$\begin{array}{l}\text { \# entries per } \\
\text { firm-year pair }\end{array}$} & \multicolumn{2}{|c|}{ All sectors } & \multicolumn{2}{|c|}{$\begin{array}{l}\text { Restricted sample } \\
\text { (7 sectors) }\end{array}$} \\
\hline & Frequency & $\begin{array}{l}\text { Cum. } \\
\text { Freq. } \\
(\%)\end{array}$ & Frequency & $\begin{array}{r}\text { Cum. } \\
\text { Freq. (\%) }\end{array}$ \\
\hline 1 & 3905 & 57.26 & 3774 & 57.55 \\
\hline 2 & 1436 & 21.05 & 1377 & 20.99 \\
\hline 3 & 690 & 10.11 & 657 & 10.01 \\
\hline 4 & 324 & 4.75 & 310 & 4.72 \\
\hline 5 & 193 & 2.83 & 181 & 2.76 \\
\hline 6 & 94 & 1.38 & 88 & 1.34 \\
\hline 7 & 55 & 0.81 & 53 & 0.81 \\
\hline 8 & 36 & 0.53 & 34 & 0.52 \\
\hline 9 & 33 & 0.48 & 32 & 0.48 \\
\hline 10 & 29 & 0.42 & 29 & 0.44 \\
\hline 11 & 13 & 0.19 & 13 & 0.19 \\
\hline 12 & 10 & 0.14 & 8 & 0.12 \\
\hline 13 & 2 & 0.03 & 2 & 0.03 \\
\hline Total firm-year & 6820 & 100 & 6558 & 100 \\
\hline
\end{tabular}

Notes: (1) In the regression analysis we do not include 34 Mexican new exporters that expanded their export portfolio in 14 or more destinations in a single year. Results are not affected if we include these firms (see previous results in the working paper). (2) In the construction of the community measure industry-by-industry we did not include firms operating in the sectors "Mineral products" (HS2digits 27-29) and "Miscellaneous products" (HS2digits 90-99).

12. Strictly speaking, we know that a new regular exporter did not export in 2000, 2001 and 2002. In our set of new regular exporters, 757 companies started to export in 2003, 948 in 2004, 1110 in 2005, 1283 in 2006 and 1928 in 2007. 
Table 1 presents a summary of our dependent variable: the number of new destinations per year served by a typical new regular exporter (the last two columns use a restricted sample for the sector-by-sector analysis). The percentage of firm-year pairs that take a value of one is $56 \%$, that is, the majority of firms in our sample that decide to expand their destination portfolio enter a single new destination. The number of firms that expand their destination portfolio in more than six destinations is very small (less than $3 \%$ of the firmyear observations). The distribution of entries per firm-year pair remains the same when we restrict the sample to 7 selected broad-defined sectors. ${ }^{13}$

13. The number of communities served by a typical new regular exporter each year is one: $75 \%$ of new regular exporters only serve one community, $14 \%$ of new regular exporters serve two communities, $6 \%$ of new regular exporters serve three communities and $5 \%$ of new regular exporters serve four or more communities. As the US is the most important destination for Mexican firms, a very large percentage of new regular exporters (84\%) serve the community in which the US is integrated; $22 \%$ serve the community of Central American countries; $13 \%$ serve the community of South American countries and another $13 \%$ the community of Asian countries. The community of small European countries is served by $5 \%$ of new regular exporters; the community of Middle East countries, the community formed by India, Indonesia and Turkey, and the community of Caribbean countries are only served by $2 \%$ of the new regular exporters. The rest of communities are served by very few Mexican new regular exporters. 


\section{Estimation results}

In this section we present the results from the econometric analyses. First, we investigate whether communities identified in the whole network of Mexican exporters determine the export path of new exporters. We also analyze whether industry-specific destinationcommunities have a larger role in determining the export path than general destinationcommunities. Second, we perform a set of sensitivity analyses to test the robustness of our results.

\subsection{Main results}

Table 2 reports estimations of the conditional logit model allowing for simultaneous exports to multiple destinations. In specification (1) we estimate the model with community as the only independent variable. The communities used in the benchmark analysis are the final communities identified in Figure 2. The community coefficient has a large positive value and is strongly statistically significant. The transformation of the community coefficients into oddsratios provides an easy way to interpret economically the estimates. ${ }^{14}$ For Mexico, the probability of choosing a new destination rises by $448 \%(=\exp (1.50))$ if it belongs to the same community of any of the firm's previous destinations.

TABLE 2. Main results. Conditional logit estimations. Baseline results. (Dependent variable: Choice of new export destination)

\begin{tabular}{|c|c|c|c|c|}
\hline Specification & (1) & (2) & (3) & (4) \\
\hline Community & $1.500 * * *(0.025)$ & $1.011 * * *(0.026)$ & $0.610 * * *(0.027)$ & $0.515 * * *(0.032)$ \\
\hline GDP & & $0.413 * * *(0.008)$ & $0.451 * * *(0.008)$ & \\
\hline Distance & & $-0.958 * * *(0.023)$ & $-0.782 * * *(0.024)$ & \\
\hline Border & & $0.222 * * *(0.037)$ & $0.554 * * *(0.039)$ & \\
\hline Language & & $0.575 * * *(0.028)$ & $0.662 * * *(0.029)$ & \\
\hline RTA & & $0.026 \quad(0.022)$ & $0.003 \quad(0.022)$ & \\
\hline Migrants & & $0.020 * * *(0.004)$ & $0.001 \quad(0.004)$ & \\
\hline I_distance 1500 & & & $0.241 * * *(0.028)$ & $0.275 * * *(0.030)$ \\
\hline I_border & & & $0.475 * * *(0.028)$ & $0.368 * * *(0.029)$ \\
\hline I_language & & & $0.253 * * *(0.025)$ & $0.312 * * *(0.037)$ \\
\hline I_RTA & & & $-0.011 \quad(0.029)$ & $0.178 * * *(0.034)$ \\
\hline I_income & & & $0.014 \quad(0.051)$ & $0.162 * * *(0.030)$ \\
\hline I_migration & & & $0.843^{* * *}(0.057)$ & $0.523 * * *(0.060)$ \\
\hline I_region & & & $0.458 * * *(0.035)$ & $0.528 * * *(0.040)$ \\
\hline $\begin{array}{l}\text { Country } \\
\text { dummies }\end{array}$ & No & No & No & Yes \\
\hline Observations & 829,900 & 829,900 & 829,900 & 829,900 \\
\hline $\mathrm{N}^{\mathrm{o}}$ of firms & 3,255 & 3,255 & 3,255 & 3,255 \\
\hline $\mathrm{N}^{\mathrm{o}}$ of countries & 65 & 65 & 65 & 65 \\
\hline Pseudo R2 & 0.05 & 0.13 & 0.15 & 0.17 \\
\hline
\end{tabular}

Notes: Clustered standard errors at the firm-level in parentheses. ${ }^{* \star *},{ }^{* \star}$ significant at 1 percent and 5 percent respectively.

Specification (2) introduces gravitational variables, such as GDP, distance, common border, common language, belonging to the same regional trade agreement and migration stocks to proxy the similarity between the domestic (Mexico) and the new export market, and the attractiveness of the new export market. There is a reduction in the size of the positive

14. The basic idea is the following: $\frac{P\left(y_{i r}=1 \mid I_{-r, t-1}^{\text {community }}=1\right)}{P\left(y_{i j}=1 \mid I_{-j, t-1}^{\text {commity }}=0\right)}=\frac{e^{\alpha I_{-r, t-1}^{\text {community }}}}{e^{\alpha I_{-j, t-1}^{\text {commity }}}}=\exp (\alpha)$ 
community coefficient and still is strongly statistically significant. According to the new coefficients, once we control for gravity measures, the probability of choosing a new destination rises by $319 \%$ in Mexico if it belongs to the same community of any of the firm's previous destinations. Regarding gravitational variables, the larger the size of the new export market the higher the probability of choosing that market as a new export destination; and the larger the bilateral distance the lower the probability of selecting the new export destination. Speaking the same language, having a land border and a higher number of migrants raise the probability of choosing the new export destination, while belonging to the same trade agreement have no impact.

Specification (3) also controls for extended-gravity measures and, again, the positive value of the community coefficient is further reduced: once we control for gravity and extended gravity measures, the probability of choosing a new export destination rises by $184 \%$ if it belongs to the same community of any of the firm's previous destinations.

Regarding extended gravity variables, having a previous export destination within 1,500 kilometers radius of the new destination raises the probability of selecting this destination. We also find that a new export destination has a larger probability of being chosen if there are previous destinations that speak the same language as this new destination, share a border, are located in the same income-quintile and region, and have sizable bilateral migration flows. In contrast, probability of being chosen is not affected when the new destination belongs to the same regional trade agreement of any previous destination.

To confirm that the community variable enhances the model's predictive capacity, we compare the probability of choosing a destination predicted by our model and by a model with extended gravity variables. In particular we calculate the percentage of cases in which the model provides a higher probability than the unconditional probability when a firm selects a destination. For selected destinations, the extended gravity model predicts a probability of selection above the unconditional probability in 53\% of cases. The model including the community variables predicts a probability above the unconditional probability in $63 \%$ of cases, which represents a 19\% improvement in predictive power.

TABLE 3. Estimations with sector-specific communities.

Dependent variable: Choice of new export destination

\begin{tabular}{lr}
\hline & \multicolumn{1}{c}{$(1)$} \\
\hline I_Community sector & $0.400^{* * *}(0.037)$ \\
I_Community no-sector & $0.331^{* * *}(0.042)$ \\
I_distance 1500 & $0.269^{* * *}(0.030)$ \\
I_border & $0.344^{* * *}(0.030)$ \\
I_language & $0.339^{* * *}(0.037)$ \\
I_RTA & $0.216^{* * *}(0.033)$ \\
I__income & $0.166^{* * *}(0.030)$ \\
I_migration & $0.485^{* * *}(0.061)$ \\
I_region & $0.580^{* * *}(0.040)$ \\
& \\
Observations & 670,290 \\
$\mathrm{~N}^{\circ}$ of firms & 3239 \\
$\mathrm{~N}^{\circ}$ of countries & 55 \\
Pseudo R2 & 0.17 \\
\hline
\end{tabular}

Notes: All estimations include destination-specific fixed effects. Clustered standard errors at the firm-level in parentheses. ${ }^{\star \star *}$ significant at 1 percent. 
Finally, specification (4) introduces destination-specific fixed effects. These fixed effects preclude the estimation of time-invariant gravity variables so, for the sake of clarity, we remove all gravity variables from the estimation. The community coefficients remain positive and statistically significant at the 1 percent level. Once we control for gravity, extended-gravity and destination-specific effects, the probability of choosing a new export destination rises by $168 \%$ if it belongs to the same community of any of its previous destinations.

Table 3 presents the results of estimating the model with industry-specific communities and rest of industries communities. Both coefficients are positive and strongly statistically significant. As we expected, the industry-specific coefficient is larger than the rest of industries community coefficient. However, the differences are small and we cannot reject the null hypothesis that both coefficients are equal. Hence, we conclude that industry-specific communities and rest of industries communities play similar roles in determining exporters' export-path.

\subsection{Sensitivity analyses}

We perform a series of sensitivity analyses to assess the robustness of our results. First, we want to confirm that the communities identified by the network-analysis algorithm do not have a strong explanatory capacity by chance. To rule out this possibility we assign destinations to communities randomly. To carry out this exercise we assume that the number of communities and the number of members within each community is the same as in the benchmark estimations. We perform the exercise 50 times; each time, once the random communities are generated we run the same model as the one in Table 2 - specification (4). In all 50 estimations the community coefficient never was positive and statistically significant.

TABLE 4. Sensitivity Analysis I. Estimations for different choices and variables. (Dependent variable: Choice of new export destination)

\begin{tabular}{|c|c|c|c|c|c|c|c|}
\hline Variables & $\begin{array}{c}(1) \\
\text { Larger } \\
\text { sample of } \\
\text { countries }\end{array}$ & $\begin{array}{c}(2) \\
\text { I_distance } \\
500\end{array}$ & $\begin{array}{c}(3) \\
\text { I_distance } \\
3000\end{array}$ & $\begin{array}{c}\text { (4) } \\
\text { New } \\
\text { exporters }\end{array}$ & $\begin{array}{c}\text { (5) } \\
\text { Count rather } \\
\text { than } \\
\text { dichotomous }\end{array}$ & No US & $\begin{array}{c}\text { (7) } \\
\text { Firm } \\
\text { network }\end{array}$ \\
\hline Community & $\begin{array}{r}0.742 * * * \\
(0.039)\end{array}$ & $\begin{array}{r}0.515^{* * *} \\
(0.032)\end{array}$ & $\begin{array}{r}0.522 * * * \\
(0.032)\end{array}$ & $\begin{array}{r}0.495 * * * \\
(0.037)\end{array}$ & $\begin{array}{r}0.210^{* * *} \\
(0.012)\end{array}$ & $\begin{array}{r}0.439 * * * \\
(0.035)\end{array}$ & $\begin{array}{r}0.322 * * * \\
(0.032)\end{array}$ \\
\hline I_dist 1500 & $\begin{array}{r}0.263 * * * \\
(0.030)\end{array}$ & & & $\begin{array}{r}0.266^{* * * *} \\
(0.033)\end{array}$ & $\begin{array}{r}0.038^{* *} \\
(0.019)\end{array}$ & $\begin{array}{r}0.250^{* * * *} \\
(0.030)\end{array}$ & $\begin{array}{r}0.213^{* * *} \\
(0.029)\end{array}$ \\
\hline I_dist 500 & & $\begin{array}{r}0.233^{* * *} \\
(0.046)\end{array}$ & & & & & \\
\hline I_dist 3000 & & & $\begin{array}{l}0.054^{*} \\
(0.033)\end{array}$ & & & & \\
\hline I_border & $\begin{array}{r}0.358 * * * \\
(0.030)\end{array}$ & $\begin{array}{r}0.283 * * * \\
(0.034)\end{array}$ & $\begin{array}{r}0.363 * * * \\
(0.030)\end{array}$ & $\begin{array}{r}0.335^{* * * *} \\
(0.032)\end{array}$ & $\begin{array}{r}0.218^{* * * *} \\
(0.024)\end{array}$ & $\begin{array}{r}0.386 * * * \\
(0.029)\end{array}$ & $\begin{array}{r}0.268^{* * *} \\
(0.029)\end{array}$ \\
\hline I_language & $\begin{array}{r}0.275 * * * \\
(0.036)\end{array}$ & $\begin{array}{r}0.315 * * * \\
(0.038)\end{array}$ & $\begin{array}{r}0.318 * * * \\
(0.038)\end{array}$ & $\begin{array}{r}0.346^{* * * *} \\
(0.040)\end{array}$ & $\begin{array}{r}0.033^{* * *} * \\
(0.010)\end{array}$ & $\begin{array}{r}0.359 * * * \\
(0.038)\end{array}$ & $\begin{array}{r}0.243^{* * *} \\
(0.037)\end{array}$ \\
\hline I_RTA & $\begin{array}{r}0.188^{* * * *} \\
(0.031)\end{array}$ & $\begin{array}{r}0.191 * * * \\
(0.034)\end{array}$ & $\begin{array}{r}0.195 * * * \\
(0.033)\end{array}$ & $\begin{array}{r}0.198 * * * \\
(0.037)\end{array}$ & $\begin{array}{r}0.030^{* * * *} \\
(0.005)\end{array}$ & $\begin{array}{r}0.257 * * * \\
(0.034)\end{array}$ & $\begin{array}{r}0.110^{* * * *} \\
(0.033)\end{array}$ \\
\hline I_income & $\begin{array}{r}0.172 * * * \\
(0.030)\end{array}$ & $\begin{array}{r}0.145^{* * *} \\
(0.031)\end{array}$ & $\begin{array}{r}0.160^{* * *} \\
(0.031)\end{array}$ & $\begin{array}{r}0.158^{* * *} \\
(0.035)\end{array}$ & $\begin{array}{r}0.073^{* * *} \\
(0.010)\end{array}$ & $\begin{array}{r}0.201^{* * *} \\
(0.031)\end{array}$ & $\begin{array}{r}0.063^{* *} \\
(0.031)\end{array}$ \\
\hline I_migration & $\begin{array}{r}0.502 * * * \\
(0.061)\end{array}$ & $\begin{array}{r}0.494 * * * \\
(0.060)\end{array}$ & $\begin{array}{r}0.515 * * * \\
(0.060)\end{array}$ & $\begin{array}{r}0.502 * * * \\
(0.066)\end{array}$ & $\begin{array}{r}0.007 \\
(0.009)\end{array}$ & $\begin{array}{r}0.446 * * * \\
(0.061)\end{array}$ & $\begin{array}{r}0.347^{* * *} \\
(0.060)\end{array}$ \\
\hline I_region & $\begin{array}{r}0.540 * * * \\
(0.038)\end{array}$ & $\begin{array}{r}0.610^{* * *} \\
(0.040)\end{array}$ & $\begin{array}{r}0.595 * * * \\
(0.040)\end{array}$ & $\begin{array}{r}0.545^{* * *} \\
(0.044)\end{array}$ & $\begin{array}{r}0.070^{* * *} \\
(0.014)\end{array}$ & $\begin{array}{r}0.560 * * * \\
(0.040)\end{array}$ & $\begin{array}{r}0.301 * * * \\
(0.041)\end{array}$ \\
\hline Firm network & & & & & & & $\begin{array}{r}1.477^{* * * *} \\
(0.086)\end{array}$ \\
\hline Observations & 829,900 & 829,900 & 829,900 & 670,078 & 829,900 & 760,481 & 829,900 \\
\hline $\mathrm{N}^{\circ}$ of firms & 3,255 & 3,255 & 3,255 & 2,774 & 3,255 & 3,096 & 3,255 \\
\hline $\mathrm{N}^{o}$ countries & 90 & 65 & 65 & 65 & 65 & 64 & 65 \\
\hline Pseudo R2 & 0.17 & 0.17 & 0.17 & 0.17 & 0.17 & 0.15 & 0.17 \\
\hline
\end{tabular}

Notes: All regressions include destination-specific fixed-effects. Clustered standard errors at the firm-level in parentheses. ${ }^{* *}$, ** significant at 1 percent and 5 percent respectively. 
Second, we analyze whether the community coefficient is robust to the use of a larger sample to identify communities. We expand the sample including the years 2000 and $2001 .^{15}$ Table 4 presents the results of estimating the model with the new samples. The community coefficient remains positive and strongly statistically significant.

Third, we analyze whether the community coefficients are robust to different extended distance variables. We re-estimate the model with a shorter distance: 500 kilometers, and a larger distance 3,000 kilometers. As shown in columns 2-3 in Table 4, the community coefficient is robust to the alternative extended-gravity distance radius.

Fourth, we use a more stringent threshold to determine whether a firm is a new exporter. Now, we define a firm as a new exporter if it does not export in 2000, 2001, 2002 and 2003. As shown in column 4 of Table 4 , the community coefficient remains positive and statistically significant and is similar to those reported in the benchmark estimation (column 4).

Fifth, we convert the community and the extended gravity variables from discrete variables to count variables, such that the community variable is the number of previous destinations that belong to the same community as the new destination. The community coefficient reduces its positive value, but remains strongly statistically significant (column 5)

Sixth, we analyze whether results for Mexico are robust to excluding all transactions with the US.. The community coefficient is very similar to the one reported in the benchmark analysis (column 6).

Seventh, we examine whether the results are affected by the inclusion of a new variable that is calculated using the trade network of Mexican firms in 2002: the (log) number of firms exporting simultaneously to the new destination and to the past destination of the firm's portfolio. We call the new variable "Firm network" in column (8). The positive and significant coefficient suggests that the probability to choose a new destination increases as the number of firms that simultaneously exported to the past portfolio and the new destination increases. The community coefficient reduces its positive value, but remains strongly statistically significant. ${ }^{16}$

Eighth, the results presented in the benchmark estimation use the final communities identified in Figure 2. In order to test the robustness of our results we also estimate the model with communities identified with fewer iterations of the modularity maximization algorithm. Table 5 presents the results of the estimations for different community hierarchies. For comparison we also reproduce the results when estimating the model with the final 10 communities in column 1. The community coefficient is always positive and statistically significant; the community coefficient only drops substantially when we only use one iteration.

15. To avoid marginal destinations, we exclude from the sample the destinations with less than 50 exporters during the period 2000-2002. The longer period and a less stringent threshold to admit a destination raises the number of destinations to 83 (65 previously). After applying iteratively the modularity maximization algorithm, we identify 12 communities. Compared to the sample used in the benchmark analyses, the number of communities rises in two (see Tables A7 in the Appendix).

16. Table $A 1$ in the Appendix shows that the global financial crisis had a negative impact on the number of firms and total value of exports in 2009. As an additional check, we investigated whether our results are affected by the global financial crisis. When we run our preferred specification year by year separately we found that estimates for year 2009 were no significantly different from those observed before 2008. 
TABLE 5. Sensitivity Analysis II: Estimations for different community hierarchies (Dependent variable: Choice of new export destination).

\begin{tabular}{|c|c|c|c|c|c|}
\hline Community type & Final & 4 iterations & 3 iterations & 2 iterations & 1 iteration \\
\hline \multirow[t]{2}{*}{ Community } & $0.515 * * *$ & $0.521 * * *$ & $0.547 * * *$ & $0.557 * * *$ & $0.410^{* * *}$ \\
\hline & $(0.032)$ & $(0.026)$ & $(0.031)$ & $(0.028)$ & $(0.034)$ \\
\hline \multirow[t]{2}{*}{ I_distance 1500} & $0.275^{* * *}$ & $0.274 * * *$ & $0.275^{* * *}$ & $0.274 * * *$ & $0.303 * * *$ \\
\hline & $(0.030)$ & $(0.027)$ & $(0.027)$ & $(0.027)$ & (0.027) \\
\hline \multirow[t]{2}{*}{ I_border } & $0.368 * * *$ & $0.367 * * *$ & $0.364 * * *$ & $0.363 * * *$ & $0.420 * * *$ \\
\hline & (0.029) & $(0.028)$ & $(0.028)$ & $(0.028)$ & (0.028) \\
\hline \multirow[t]{2}{*}{ I_language } & $0.312 * * *$ & $0.312 * * *$ & $0.316^{* * *}$ & $0.310^{* * *}$ & $0.401 * * *$ \\
\hline & $(0.037)$ & $(0.034)$ & $(0.034)$ & $(0.034)$ & $(0.033)$ \\
\hline \multirow[t]{2}{*}{ I_RTA } & $0.178 * * *$ & $0.177 * * *$ & $0.166^{* * *}$ & $0.163 * * *$ & $0.272 * * *$ \\
\hline & $(0.034)$ & $(0.033)$ & $(0.033)$ & (0.033) & $(0.032)$ \\
\hline \multirow[t]{2}{*}{ I_income } & $0.162 * * *$ & $0.159 * * *$ & $0.153^{* * *}$ & $0.146^{* * *}$ & $0.274 * * *$ \\
\hline & $(0.030)$ & (0.029) & $(0.031)$ & (0.029) & (0.029) \\
\hline \multirow[t]{2}{*}{ I_migration } & $0.523 * * *$ & $0.519 * * *$ & $0.503 * * *$ & $0.501 * * *$ & $0.431 * * *$ \\
\hline & $(0.060)$ & $(0.054)$ & $(0.057)$ & $(0.057)$ & $(0.058)$ \\
\hline \multirow[t]{2}{*}{ I_region } & $0.528 * * *$ & $0.529 * * *$ & $0.525 * * *$ & $0.553 * * *$ & $0.598 * * *$ \\
\hline & $(0.040)$ & $(0.032)$ & $(0.032)$ & $(0.032)$ & (0.032) \\
\hline Observations & 829,900 & 829,900 & 829,900 & 829,900 & 829,900 \\
\hline $\mathrm{N}^{\mathrm{o}}$ of firms & 3,255 & 3,255 & 3,255 & 3,255 & 3,255 \\
\hline $\mathrm{N}^{o}$ of countries & 65 & 65 & 65 & 65 & 65 \\
\hline R2 & 0.17 & 0.17 & 0.17 & 0.17 & 0.17 \\
\hline
\end{tabular}

Votes: All estimations include destination-specific fixed effects. Clustered standard errors at the firm-level in parentheses. ***, **, * significant at 1 percent and 5 percent respectively.

Ninth, the conditional logit model imposes a strong restriction: Independence Irrelevant Alternatives (IIA) assumption. The IIA states that the ratio of the probabilities of choosing a new export market only depends on the attributes of the two destinations, and is independent on the characteristics of other destinations. However, this restriction fails if some destinations have some (unobserved) common characteristics, making substitution among them easier. If the IIA restriction does not hold the conditional logit model leads to biased estimates. To address this limitation, we estimate alternative logit models that relax the $\| A$ assumption: the nested-logit model and the mixed logit model. ${ }^{17}$ As shown in Table 6, in both the nested and mixed logit models, the community coefficient remains positive and statistically significant.

TABLE 6. Sensitivity Analysis III: Nested-Logit and Mixed -Logit model estimations. (Dependent variable: Choice of new export destination)

\begin{tabular}{|l|rrr|}
\hline Variables & Nested-Logit & $\begin{array}{c}\text { Mixed-Logit } \\
\text { Mean }\end{array}$ & $\begin{array}{c}\text { Mixed-logit } \\
\text { Standard deviation }\end{array}$ \\
\hline Community & $0.715^{* * *}(0.031)$ & $0.472^{* * *}(0.028)$ & $0.529^{* * *}(0.043)$ \\
I_distance 1500 & $0.564^{* * *}(0.040)$ & $0.146^{* *}(0.009)$ & $0.022(0.080)$ \\
I_border & $0.627^{* * *}(0.043)$ & $0.336^{* * *}(0.127)$ & $0.103(0.070)$ \\
I_language & $0.452^{* * *}(0.037)$ & $0.273^{* * *}(0.027)$ & $0.017(0.089)$ \\
I_RTA & $0.334^{* * *}(0.036)$ & $-0.057^{*}(0.042)$ & $0.313^{* * *}(0.061)$ \\
I_income & $0.225^{* * *}(0.032)$ & $0.129 * * *(0.034)$ & $0.335^{* * *}(0.072)$ \\
I_migration & $0.705^{* * *}(0.071)$ & $0.798^{* * *}(0.073)$ & $0.473^{* *}(0.172)$ \\
I_region & & $0.401^{* * *}(0.035)$ & $0.564^{* * *}(0.053)$ \\
LR-Test for IIA & 105.27 & & 829900 \\
(phi value) & $(0.00)$ & & \\
N observ. & 829900 & 829900 & \\
\hline
\end{tabular}

Notes: The mixed-logit estimation also includes gravity-type controls. Standard deviation in parentheses. ${ }^{* \star *}$, ${ }^{\star *},{ }^{*}$ significant at 1 percent, 5 percent and 10 percent respectively.

17. To implement the nested logit model we should determine a nesting criterion. We start assuming that firms decide, first, what major world region they want to sell to and, second, they select the destination within that region. We also used alternative nesting criteria, such as dividing destinations into close markets and distant markets, which no major changes in results. To estimate the nested logit model we assign destinations to one of the seven major regions defined by the World Bank (see footnote 11) 
Finally we repeat all the estimations with an alternative sample: we restrict the analysis to those firms that expand their export portfolio in only one destination per year. Table 7 reports the results. The main conclusion is that the sign and coefficient of the explanatory variables of the empirical model are not affected when we restrict the sample.

To sum up, the sensitivity analyses show that the positive and significant contribution of belonging to a community in determining the dynamics of firms' new export destinations is robust to the use of different samples and econometric specifications. We also show that this positive relation does not arise randomly.

TABLE 7. Sensitivity Analysis IV (Dependent variable: Choice of new export destination). Sample: Firms that expand export portfolio by one destination only

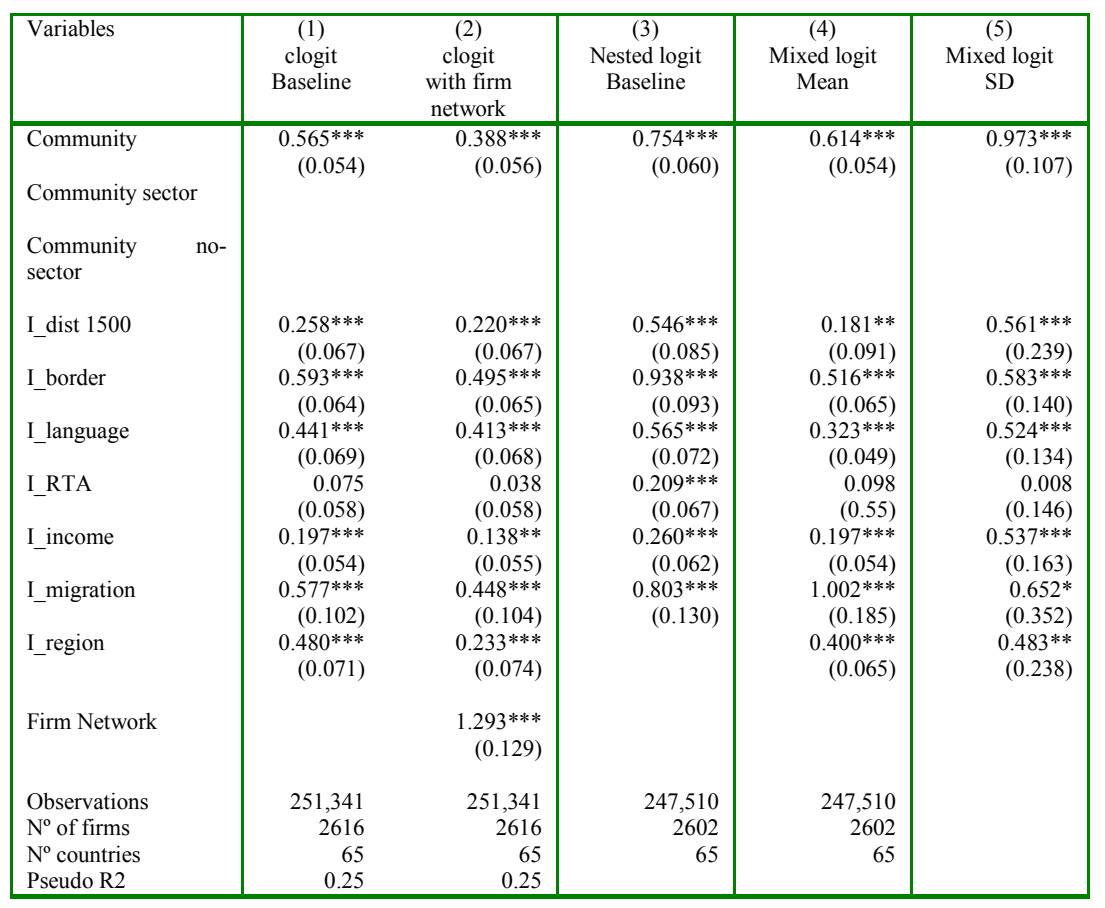

Notes: Columns (1)-(3) include destination-specific fixed-effects. Clustered standard errors at the firm-level in parentheses. ***, ${ }^{\star *}$ significant at 1 percent and 5 percent respectively. 


\section{Conclusions}

How do exporters choose new export destinations? While there are many factors that are important for this decision, an empirical regularity strikes out: firms tend to choose new export markets that are similar to their prior export destinations. Network analysis, through the community-detection algorithm, provides a tool to identify destinations that share a common set of characteristics. This measure has advantages over the gravity measures. First, it is an agnostic approach using a purely outcome-based measure and, hence, encapsulates all the observable and non-observable factors that may influence the degree of similarity among destinations. Second, it is a country-specific measure. Third, it allows the calculation of industry-specific similarity measures.

We apply this methodology to the web of Mexican exporters' destinations and find that there are ten communities in the Mexican web (of 65 countries). Next we show that belonging to the same community of a previous export destination exerts a strong influence on the dynamics of the exporter. In particular, the probability of choosing a new destination multiplies by three if it belongs to the same community of any of firm's previous destinations. We show that the strong predictive capacity of the network-based similarity measure remains once we control for gravity measures. We also show that industry-specific community of destinations and general community of destinations exert a similar influence on the dynamics of Mexican exporters' destination-portfolio. Results are robust to different specifications and samples.

We conclude, based on our research that it can be useful to take into account the destination network of regular exporters in order to design trade-enhancing policies orientated to expand the destination portfolio of exporters trying to concentrate efforts on countries belonging to the same community to that of previous export destinations. For incumbent firms the decision process about the first export destination should incorporate information not only about the finally selected country but it should consider the community as a potential market to be served. For international trade agreements, the community structure has political considerations because a bilateral trade agreement might have also positive spillovers over the countries belonging to the same community, as it will also foster trade with them. Sectorspecific communities might be useful for industrial policy. Furthermore, the paper would support the implementation of trade promotion practices aimed at increasing the expansion to similar destination markets to those ones in which the company has export experience. That is, the probability of success of these trade policies would be higher, given the significant tendency of firms to optimize their efforts in foreign markets by remaining in closely related areas ('communities'). 


\section{Appendix. Data sources}

Our firm-level data comes from transaction-level customs data on the universe of Mexican exporters over the period 2000-2009. The source for the data is detailed in the Annex of Cebeci et al. (2012) and the data was collected by the Trade and Integration Unit of the World Bank Research Department, as part of their efforts to build the Exporter Dynamics Database. In the Mexican dataset the firm identification code changes from 2007 onwards. For the year 2007 we have data with the old firm classification and with the new firm classification. Matching firm-level country and HS 6-digit specific records we can establish a correspondence between the old firm classification and the new firm classification for firms that exported in 2007. For the rest of firms that exported in 2008 and/or 2009, we cannot know whether they are new exporters or they are firms that exported in the 2000-2006 period. Since we use data on year 2002 for the network analysis and the sample of entrants that export at three consecutive years for the analysis of the dynamics of destination portfolio, this problem in the raw data does not affect our analysis. Table A1 in the Appendix display information on the number of trading firms, number of transactions and value (in millions US\$) in the 2000-2009 period.

Data for the construction of the gravity and extended-gravity measures come from different sources. Data on income and population are taken from World Bank (2012). Distance, contiguity, common language, colonial relationship and same continent are obtained from Head et al. (2010). Bilateral migration stocks in 2000 are from Özden et al. (2011) and common membership in a regional trade agreement (RTA) in 2002 is obtained from de Sousa et al. (2012). The web links for databases open to the public are: World Development Indicators: http://data.worldbank.org/data-catalog/world-developmentindicators; CEPII gravity dataset: http://www.cepii.fr/anglaisgraph/bdd/gravity.asp; RTA database: http://kellogg.nd.edu/faculty/fellows/bergstrand.shtml; World Bilateral Migration database: http://data.worldbank.org/data-catalog/global-bilateral-migration-database. 
TABLE A1. Mexican exporters database (2000-2009)

\begin{tabular}{|c|c|c|c|c|c|c|c|c|c|c|}
\hline & 2000 & 2001 & 2002 & 2003 & 2004 & 2005 & 2006 & 2007 & 2008 & 2009 \\
\hline Number of exporting firms & 35.509 & 34.318 & 31.592 & 30.420 & 30.441 & 30.984 & 30.171 & 30.283 & 29.796 & 28.690 \\
\hline Number of transactions & 183.586 & 181.343 & 171.029 & 161.899 & 167.905 & 173.620 & 174.308 & 187.267 & 190.584 & 183.036 \\
\hline Value of exports (current US\$ million) & 165.974 & 158.539 & 160.669 & 164.941 & 187.736 & 213.902 & 249.510 & 270.776 & 290.160 & 228.728 \\
\hline Regular exporters ( $\mathrm{N}=5697)$ (\% firms) & $16 \%$ & $17 \%$ & $18 \%$ & $19 \%$ & $19 \%$ & $18 \%$ & $19 \%$ & $19 \%$ & $19 \%$ & $20 \%$ \\
\hline$\%$ total transactions & $35 \%$ & $38 \%$ & $40 \%$ & $40 \%$ & $43 \%$ & $46 \%$ & $46 \%$ & $46 \%$ & $46 \%$ & $46 \%$ \\
\hline$\%$ value of total exports & $60 \%$ & $64 \%$ & $65 \%$ & $66 \%$ & $66 \%$ & $66 \%$ & $67 \%$ & $67 \%$ & $68 \%$ & $69 \%$ \\
\hline Regular new exporters & & & & 757 & 948 & 1.110 & 1.283 & 1.928 & & 6.026 \\
\hline (\% in total firms) & & & & $2 \%$ & $3 \%$ & $4 \%$ & $4 \%$ & $6 \%$ & & $21 \%$ \\
\hline Transactions & & & & 3.207 & 3.907 & 5.081 & 5.145 & 7.177 & & 41.571 \\
\hline (\% in total transactions) & & & & $2 \%$ & $2 \%$ & $3 \%$ & $3 \%$ & $4 \%$ & & $23 \%$ \\
\hline Value of exports & & & & 30.890 & 29.351 & 28.498 & 33.411 & 62.596 & & 47.805 \\
\hline (\% in total exports) & & & & $19 \%$ & $16 \%$ & $13 \%$ & $13 \%$ & $23 \%$ & & $21 \%$ \\
\hline & & & & & & & & & & \\
\hline Merchandise exports (Source: WDI) & 166.367 & 158.547 & 160.682 & 165.396 & 187.980 & 214.207 & 249.961 & 271.821 & 291.265 & 229.712 \\
\hline
\end{tabular}

Notes: The term "firm" refers to any individual operator that makes a transaction in a year. The dataset contains all the transactions with a value above 1,500US\$. The area in dark grey refers to the number of firms, number of transactions and value of exports in 2009 of the new regular exporters, that is, firms that started exporting after 2003 and did not stop exporting until 2009 (our Mexican firms sample).

एسلس

\begin{tabular}{|c|c|c|c|c|c|c|}
\hline & (1) & (2) & (3) & (4) & (5) & (6) \\
\hline & & & & & & $\begin{array}{r}\text { Regular } \\
\text { exporters }\end{array}$ \\
\hline Type of firm & New exporting & is since & 003 that $\mathrm{c}$ & not stop & orting & 2000-2009 \\
\hline Years exporting & 03-04 & $04-05$ & $05-06$ & $06-07$ & $07-08$ & 07-08 \\
\hline \# new regular exporters & 757 & 948 & 1110 & 1283 & 1928 & \\
\hline \# firms in each period & 757 & 1705 & 2815 & 4098 & 6026 & 5697 \\
\hline \multicolumn{7}{|l|}{ Changes in country portfolio (\%) } \\
\hline Only entries & 21 & 17 & 15 & 14 & 15 & 16 \\
\hline Only exits & 4 & 6 & 8 & 8 & 9 & 7 \\
\hline \multicolumn{7}{|l|}{ Simultaneous entry \& exit } \\
\hline same entries and exits & 5 & 6 & 5 & 6 & 6 & 6 \\
\hline entries>exits & 8 & 7 & 7 & 7 & 7 & 7 \\
\hline entries < exits & 1 & 3 & 4 & 4 & 4 & 3 \\
\hline No change in portfolio & 61 & 62 & 61 & 61 & 60 & 61 \\
\hline
\end{tabular}

Source: Own elaboration using Census of Exporting Mexican Firms, 2000-2009. 
TABLE A3. Gravity equation for all sectors and sector-by-sector. Dependent variable: Number of Mexican firms in 2002 that exported simultaneously to destinations $\mathrm{i}$ and $\mathrm{j}$

\begin{tabular}{|c|c|c|c|c|c|c|c|c|}
\hline VARIABLES & $\begin{array}{c}0 \\
\text { All sectors } \\
\end{array}$ & $\begin{array}{c}1 \\
\text { Agriculture }\end{array}$ & $\begin{array}{c}2 \\
\text { Chemicals } \\
\end{array}$ & $\begin{array}{c}3 \\
\text { Machiney } \\
\end{array}$ & $\begin{array}{c}4 \\
\text { Metals } \\
\end{array}$ & $\begin{array}{c}5 \\
\text { Non-mineral } \\
\end{array}$ & $\begin{array}{c}6 \\
\text { Paper } \\
\end{array}$ & $\begin{array}{c}7 \\
\text { Textile } \\
\end{array}$ \\
\hline Igdp_ij & $\begin{array}{c}0.205^{* * *} \\
{[0.025]}\end{array}$ & $\begin{array}{c}0.339 * * * \\
{[0.031]}\end{array}$ & $\begin{array}{c}-4.991 * * * \\
{[0.365]}\end{array}$ & $\begin{array}{c}0.198 * * * \\
{[0.014]}\end{array}$ & $\begin{array}{c}0.419 * * * \\
{[0.026]}\end{array}$ & $\begin{array}{c}-13.292^{* * *} \\
{[0.855]}\end{array}$ & $\begin{array}{c}0.405^{* * *} \\
{[0.046]}\end{array}$ & $\begin{array}{c}-11.515^{* * *} \\
{[0.517]}\end{array}$ \\
\hline Idist_ij & $\begin{array}{c}-0.311^{* * *} \\
{[0.010]}\end{array}$ & $\begin{array}{c}-0.380 * * * \\
{[0.015]}\end{array}$ & $\begin{array}{c}-0.240 * * * \\
{[0.018]}\end{array}$ & $\begin{array}{c}-0.257^{* * *} \\
{[0.012]}\end{array}$ & $\begin{array}{c}-0.315^{* * *} \\
{[0.013]}\end{array}$ & $\begin{array}{c}-0.267^{* * *} \\
{[0.024]}\end{array}$ & $\begin{array}{c}-0.274^{* * *} \\
{[0.018]}\end{array}$ & $\begin{array}{c}-0.309 * * * \\
{[0.016]}\end{array}$ \\
\hline border_ij & $\begin{array}{c}-0.140 * * * \\
{[0.030]}\end{array}$ & $\begin{array}{c}-0.103^{* *} \\
{[0.044]}\end{array}$ & $\begin{array}{c}0.042 \\
{[0.057]}\end{array}$ & $\begin{array}{c}-0.179 * * * \\
{[0.029]}\end{array}$ & $\begin{array}{c}-0.153^{* * *} \\
{[0.036]}\end{array}$ & $\begin{array}{c}-0.209 * * * \\
{[0.041]}\end{array}$ & $\begin{array}{c}-0.070 \\
{[0.059]}\end{array}$ & $\begin{array}{c}-0.190 * * * \\
{[0.038]}\end{array}$ \\
\hline language_ij & $\begin{array}{c}0.214^{* * *} \\
{[0.020]}\end{array}$ & $\begin{array}{c}0.170 * * * \\
{[0.031]}\end{array}$ & $\begin{array}{l}0.080^{* *} \\
{[0.033]}\end{array}$ & $\begin{array}{c}0.124^{* * *} \\
{[0.020]}\end{array}$ & $\begin{array}{c}0.221 * * * \\
{[0.025]}\end{array}$ & $\begin{array}{c}0.333^{* * *} \\
{[0.046]}\end{array}$ & $\begin{array}{c}0.222^{* * *} \\
{[0.043]}\end{array}$ & $\begin{array}{c}0.126 * * * \\
{[0.026]}\end{array}$ \\
\hline comcol_ij & $\begin{array}{c}0.088 \\
{[0.060]}\end{array}$ & $\begin{array}{c}0.002 \\
{[0.163]}\end{array}$ & $\begin{array}{c}0.063 \\
{[0.170]}\end{array}$ & $\begin{array}{c}0.112 \\
{[0.118]}\end{array}$ & $\begin{array}{l}0.167^{*} \\
{[0.100]}\end{array}$ & $\begin{array}{c}0.271 \\
{[0.259]}\end{array}$ & $\begin{array}{c}0.113 \\
{[0.136]}\end{array}$ & $\begin{array}{c}0.017 \\
{[0.130]}\end{array}$ \\
\hline rta_ij & $\begin{array}{l}-0.005 \\
{[0.011]}\end{array}$ & $\begin{array}{c}-0.043^{* *} \\
{[0.020]}\end{array}$ & $\begin{array}{c}0.017 \\
{[0.019]}\end{array}$ & $\begin{array}{c}0.017 \\
{[0.011]}\end{array}$ & $\begin{array}{l}-0.021 \\
{[0.017]}\end{array}$ & $\begin{array}{c}0.045^{* * *} \\
{[0.013]}\end{array}$ & $\begin{array}{c}-0.071 * * * \\
{[0.023]}\end{array}$ & $\begin{array}{c}0.017 \\
{[0.014]}\end{array}$ \\
\hline $\begin{array}{l}\text { Observations } \\
\text { R-squared }\end{array}$ & $\begin{array}{l}2080 \\
0.976\end{array}$ & $\begin{array}{l}1485 \\
0.908\end{array}$ & $\begin{array}{l}1485 \\
0.963\end{array}$ & $\begin{array}{l}1485 \\
0.982\end{array}$ & $\begin{array}{l}1485 \\
0.963\end{array}$ & $\begin{array}{l}1485 \\
0.981\end{array}$ & $\begin{array}{l}1485 \\
0.928\end{array}$ & $\begin{array}{l}1485 \\
0.973\end{array}$ \\
\hline
\end{tabular}

Notes: All sectors sample contains 65 destinations. N=2080 [=65*64)/2]. Sector by sector samples contain 55 destinations: $\mathrm{N}=1485$ [=(55*54)/2] observations. Estimation method: Pseudo-Poisson Maximum Likelihood. All regressions include origin (i) and destination (j) fixed effects. Explanatory variables: Igdp_ij is the log of the product of GDP from country $i$ and GDP of country j; Idist_ij is the log of bilateral geodesic distance; border_ij is a dummy that takes value of 1 if countries i\&j share a common land border; language $\_$ij is a dummy that takes value of 1 if countries i\&j share a common official language; rta $\_i j$ is a dummy that takes value of 1 if countries i\&j are members of the same regional trade agreements. See Appendix: Data sources for information on data sources. 
TABLE A4. Comparison of similarity between communities obtained from raw data and from predicted gravity

\begin{tabular}{lccccr}
\hline & $\begin{array}{c}\text { Number } \\
\text { communites } \\
\text { Raw }\end{array}$ & Gravity \\
data & Degree of similarity \\
& 10 & 4 & 0.175 & 1.579 \\
\hline All sectors & & & & RAND & VI \\
1. Agriculture & 8 & 3 & 0.262 & 1.612 \\
2. Chemicals & 10 & 2 & 0.002 & 2.335 \\
3. Machinery \& transport equipment & 6 & 3 & 0.213 & 1.504 \\
4. Metals & 9 & 3 & 0.168 & 1.713 \\
5. Non-metallic minerals & 9 & 6 & 0.065 & 2.635 \\
6. Paper & 5 & 2 & 0.129 & 1.532 \\
7. Textiles & 7 & 2 & 0.012 & 1.812 \\
\hline
\end{tabular}

Notes: $\mathrm{VI}=$ Variation of information; RAND $=$ adjusted RAND index. $\mathrm{Vl}=0$ indicates maximum similarity in the distribution. The RAND index varies between 0 and 1 ; a value of 0 means no matching (i.e. maximum dissimilarity). 
TABLE A5. Communities by sectors. Mexico 2002

\begin{tabular}{|c|c|c|c|c|c|c|}
\hline Agriculture & Chemicals & $\begin{array}{c}\text { Machinery \& } \\
\text { Transport equipment }\end{array}$ & Metals & $\begin{array}{c}\text { Non-metallic } \\
\text { minerals }\end{array}$ & Paper & Textiles \\
\hline ARG & $\mathrm{BOL}$ & CHL & BOL & $\mathrm{ARG}$ & CHL & CHL \\
\hline BOL & $\mathrm{CHL}$ & $\mathrm{COL}$ & CHL & BRA & $\mathrm{COL}$ & $\mathrm{COL}$ \\
\hline BRA & $\mathrm{COL}$ & CRI & $\mathrm{COL}$ & CHL & CRI & CRI \\
\hline $\mathrm{CHL}$ & CUB & CUB & $\mathrm{ECU}$ & $\mathrm{COL}$ & CUB & CUB \\
\hline $\mathrm{COL}$ & ECU & DOM & PER & ECU & DOM & DOM \\
\hline DOM & PAN & ECU & VEN & ESP & ECU & ECU \\
\hline ECU & PER & GTM & BHS & PER & GTM & GTM \\
\hline PER & VEN & HND & BLZ & VEN & HND & HND \\
\hline PRI & BHS & NIC & BRB & BLZ & JAM & NIC \\
\hline VEN & BRB & PAN & HTI & GRC & NIC & PAN \\
\hline BHS & JAM & PER & JAM & HTI & PAN & PER \\
\hline BLZ & TTO & SLV & TTO & JAM & SLV & PRI \\
\hline $\mathrm{BRB}$ & CRI & USA & CRI & TTO & VEN & SLV \\
\hline CUB & DOM & VEN & CUB & BHS & $\overline{\mathrm{ARG}}$ & VEN \\
\hline HTI & GTM & BHS & DOM & CHE & BRA & BZL \\
\hline JAM & HND & BLZ & GTM & CRI & CAN & BOL \\
\hline TTO & NIC & $\mathrm{BOL}$ & HND & CUB & HKG & BRB \\
\hline URY & SLV & BRB & NIC & DOM & IDN & HTI \\
\hline CRI & ARE & HTI & PAN & GTM & KOR & JAM \\
\hline GTM & $\mathrm{CHN}$ & JAM & PRI & HND & MYS & TTO \\
\hline HND & HKG & PRI & SLV & NIC & PER & $\mathrm{CHN}$ \\
\hline NIC & IDN & TTO & HKG & PAN & PHL & HKG \\
\hline PAN & KOR & $\overline{\mathrm{ARG}}$ & HUN & PRI & URY & HUN \\
\hline SLV & THA & IDN & MYS & SLV & AUS & THA \\
\hline$\overline{\mathrm{CHN}}$ & TWN & MYS & NLD & USA & AUT & TWN \\
\hline KOR & AUS & NZL & SGP & $\overline{\mathrm{ARE}}$ & BEL & BRA \\
\hline PHL & GRC & PHL & THA & IDN & BHS & CAN \\
\hline THA & MYS & SGP & TWN & KOR & BRB & CHE \\
\hline$\overline{\mathrm{HKG}}$ & NLZ & THA & AUS & THA & CAN & DEU \\
\hline IDN & PHL & TWN & AUT & TWN & DEU & IDN \\
\hline NZL & SGP & URY & BEL & $\mathrm{CHN}$ & ESP & KOR \\
\hline SGP & $\overline{D E U}$ & ZAF & BRA & HKG & FIN & PHL \\
\hline TWN & ESP & AUS & $\mathrm{CHN}$ & JPN & FRA & SWE \\
\hline AUS & FRA & BEL & GBR & PHL & GBR & USA \\
\hline BEL & GBR & BRA & JPN & ZAF & GRC & ARE \\
\hline CAN & ITA & CAN & KOR & CAN & HUN & BEL \\
\hline CHE & JPN & $\mathrm{CHN}$ & ZAF & FRA & ITA & BHS \\
\hline DEU & BLZ & DEU & CAN & GBR & JPN & ESP \\
\hline ESP & $\mathrm{CAN}$ & ESP & CHE & ITA & NLD & FRA \\
\hline GRA & HTI & FRA & DEU & SAU & NZL & GRC \\
\hline GBR & PRI & GBR & ESP & SWE & PRI & ITA \\
\hline ITA & USA & HKG & FRA & FIN & PRT & NLD \\
\hline JPN & FIN & ITA & ITA & MYS & SAU & PRT \\
\hline NLD & HUN & JPN & USA & NLZ & SWE & AUS \\
\hline SWE & SAU & KOR & ARE & BOL & TWN & FIN \\
\hline USA & $\mathrm{ARG}$ & NLD & SAU & HUN & USA & GBR \\
\hline ARE & BRA & ARE & ARG & SGP & ARE & JPN \\
\hline GRC & PRT & FIN & IDN & URY & BLZ & MYS \\
\hline MYS & URY & GRC & PHL & AUS & BOL & SGP \\
\hline PRT & $\mathrm{ZAF}$ & SAU & URY & AUT & SGP & ZAF \\
\hline SAU & AUT & AUT & FIN & BEL & THA & ARG \\
\hline$\overline{\text { AUT }}$ & BEL & CHE & GRC & BRB & TTO & AUT \\
\hline FIN & CHE & HUN & NZL & DEU & CHE & NZL \\
\hline HUN & NLD & PRT & PRT & NLD & HTI & SAU \\
\hline ZAF & SWE & SWE & SWE & PRT & ZAF & URY \\
\hline
\end{tabular}


TABLE A6. Adjusted Rand indexes

\begin{tabular}{|c|c|c|c|c|c|c|c|c|}
\hline & Agriculture & Chemicals & $\begin{array}{c}\text { Machinery \& } \\
\text { Transport } \\
\text { equipment }\end{array}$ & Metals & $\begin{array}{l}\text { Non-metallic } \\
\text { minerals }\end{array}$ & Paper & Textiles & $\begin{array}{c}\text { Industry partitions } \\
\text { vs. rest of industries } \\
\text { partitions }\end{array}$ \\
\hline ture & 1.00 & & & & & & & 0.36 \\
\hline als & 0.31 & 1.00 & & & & & & 0.14 \\
\hline \multirow[t]{2}{*}{ ery\&Transport } & 0.34 & 0.32 & 1.00 & & & & & 0.38 \\
\hline & 0.37 & 0.31 & 0.38 & 1.00 & & & & 0.25 \\
\hline \multirow[t]{2}{*}{ tallic minerals } & 0.26 & 0.24 & 0.24 & 0.32 & 1.00 & & & 0.31 \\
\hline & 0.23 & 0.16 & 0.28 & 0.18 & 0.17 & 1.00 & & 0.31 \\
\hline ; & 0.26 & 0.25 & 0.41 & 0.35 & 0.23 & 0.25 & 1.00 & 0.22 \\
\hline
\end{tabular}

TABLE A7. Community detection process in the network of Mexican exporters' destinations using the 2000-2002 sample

\begin{tabular}{|l|}
\hline ARG, BOL, CHL, COL, ECU, PER, PRY, URY, VEN \\
\hline BLZ, CRI, CUB, DOM, GTM, HND, NIC, PAN, PRI, SLV \\
\hline DMA, HTI, JAM, SUR, TTO \\
\hline ABW, ANT, ATG, BHS, BMU, BRB, CYM, LCA, VCT, GUY \\
\hline BEL, BRA, CAN, CHE, DEU, ESP, FRA, GBR, ITA, JPN, NLD, USA \\
\hline ARE, EGY, JOR, KWT, LBN, SAU, SYR \\
\hline DZA, LKA, MAR, PAK, TUR \\
\hline DNK, FIN, NOR, SWE \\
\hline AUT, CZE, HUN, IRL \\
\hline NGA, VGB \\
\hline CHN, HKG, IDN, IND, KOR, MYS, PHL, PRK, SGP, THA, TWN, VNM \\
\hline AUS, NZL, ZAF \\
\hline
\end{tabular}

TABLE A8. Summary statistics of explanatory variables in Table 2

\begin{tabular}{lrrrr} 
Variable & Mean & Std. Dev & Minimum & Maximum \\
\hline Choice & .0164 & .127 & 0 & 1 \\
community & .273 & .445 & 0 & 1 \\
Ln GDP & 1.204 & 1.869 & 6.962 & 1.648 \\
Ln DISTANCE & 8.859 & .687 & 7.263 & 9.697 \\
Border & .0342 & .181 & 0 & 1 \\
Language & .2987 & .457 & 0 & 1 \\
RTA & .4151 & .492 & 0 & 1 \\
Ln migration & 5.925 & 2.425 & 0 & 16.028 \\
I_distance1500 & .1230 & .328 & 0 & 1 \\
I_border & .1035 & .304 & 0 & 1 \\
I_language & .3895 & .487 & 0 & 1 \\
I_region & .4608 & .498 & 0 & 1 \\
I_income & .6070 & .488 & 0 & 1 \\
I_migration & .8534 & .353 & 0 & 1 \\
I_RTA & .3959 & .489 & 0 & 1 \\
\hline
\end{tabular}




\section{REFERENCES}

ALBORNOZ, F., CALVO-PARDO, H., CORCOS, G., and ORNELAS, E. (2012), "Sequential exporting", Journal of International Economics, 88, 1, 17-31.

BARIGOZZI, M., FAGIOLO, G. and MANGIONI, G. (2011), "Identifying the Community Structure of the InternationalTrade Multi Network", Physica A, 390, 2051-2066.

BERNARD, A.B., JENSEN B.J., REDDING, S. J. and SCHOTT, P.K. (2009), "The Margins of US Trade", American Economic Review, 99(2), 487-93.

BESEDES, T. and PRUSA, TH. (2011), "The Role of Extensive and Intensive Margins and Export Growth", Journal of Development Economics, 96(2), 371-379.

BLONDEL, V. D., GUILLAUME, J.L., LAMBIOTTE, R. and LEFEBVRE, E. (2008), "Fast unfolding of communities in large networks", Journal of Statistical Mechanics: Theory and Experiment, October, P10008.

CEBECI, T., FERNANDES, A.M., FREUND, C. and PIEROLA, M.D. (2012), "Exporter Dynamics Database", World Bank Policy Research Paper 6229

CHANEY, T. (2011), "The network structure of international trade", NBER Working Paper 16753.

DE BENEDICTIS, L. and TAJOLI, L. (2011), "The World Trade Network", The World Economy, 34, 8, 1417-1454.

DE SOUSA, J., MAYER, T. and ZIGNANO, S. (2012), "Market access in global and regional trade", Regional Science and Urban Economics, 42, 6, 1037-1052.

DEFEVER, F., HEID, B. and LARCH, M. (2015), "Spatial exporters", Journal of International Economics, 1, 145-156.

DUEÑAS, M. and FAGIOLO, G. (2013), "Modeling the International-Trade Network: A Gravity Approach", Journal of Economic Interaction and Coordination, 8, 155-178.

EATON, J., ESLAVA, M. KUGLER, M., TYBOUT, J. (2007), "Export Dynamics in Colombia: Firm-Level Evidence”, NBER Working Paper 135131.

EVENETT, S.J. and VENABLES, A. J. (2002), "Export Growth in Developing Countries: Market Entry and Bilateral Trade Flows", University of Bern Working Paper, mimeo.

FAGIOLO, G., REYES, J. and SCHIAVO, S. (2009), "The World-Trade Web: Topological Properties, Dynamics, and Evolution", Physical Review E, 79, 036115, 109.

FORTUNATO, S. and BERTHÉLEMY, M. (2007), "Resolution limit in community detection", Proceedings of the National Academy of Sciences, 104, 1, 36-41.

FRANKEL, J., STEIN, E. and WEI, S. (1995), "Trading Blocs and the Americas: The Natural, the Unnatural, and the Super-Natural", Journal of Development Economics, 47, 1, 61-95.

HUBERT, L. and ARABIE, P. (1985), "Comparing partitions", Journal of Classification, 2, 1, 193-218.

KALI, R. and REYES, J. (2007), "The architecture of globalization: a network approach to international economic integration", Journal of International Business Studies, 38, 4, 595-620.

LAWLESS, M. (2013), "Marginal Distance: Does Export Experience Reduce Firm Trade Costs?," Open Economies Review, 24(5), 819-841.

LINDER, S. (1961), "An Essay on Trade and Transformation", (Stockholm: Almqvist \& Wiksell).

MCFADDEN, D. (1974), "Conditional Logit Analysis of Qualitative Choice Behavior", in P. Zarembka (eds.), Frontiers in Econometrics, New York: Academic Press, 105-142.

MEILA, M. (2007), "Comparing clusterings - an information based distance", Journal of Multivariate Analysis 98 (5), $873-$ 895.

MORALES, E., SHEU, G., ZAHLER, A. (2014), "Gravity and Extended Gravity: Using Moment Inequalities to Estimate a Model of Export Entry", NBER Working Paper No. 19916

NEWMAN, M.E. (2006), "Modularity and community structure in networks", Proceedings of the National Academy of Sciences, 103, 23, 8577-8582

NGUYEN, D. X. (2012), "Demand uncertainty: Exporting delays and exporting failures", Journal of International Economics, 86, 2, 336-344.

ÖZDEN, C., PARSONS, C.R., SCHIFF, M. and WALMSLEY, T.L. (2011), "Where on Earth is Everybody? The Evolution of Global Bilateral Migration 1960-2000", World Bank Policy Research Working Paper 5709.

RAND, W. M. (1971), "Objective criteria for the evaluation of clustering methods", Journal of the American Statistical Association, 66 (336), 846-850.

REYES, J., WOOSTER, R. and SHIRRELL, S. (2014), "Regional Trade Agreements and the Pattern of Trade: A Networks Approach", The World Economy, 37, 8, 1128-1151. 


\title{
BANCO DE ESPAÑA PUBLICATIONS
}

\author{
WORKING PAPERS
}

1401 TERESA SASTRE and FRANCESCA VIANI: Countries' safety and competitiveness, and the estimation of current account misalignments.

1402 FERNANDO BRONER, ALBERTO MARTIN, AITOR ERCE and JAUME VENTURA: Sovereign debt markets in turbulent times: creditor discrimination and crowding-out effects.

1403 JAVIER J. PÉREZ and ROCÍO PRIETO: The structure of sub-national public debt: liquidity vs credit risks.

1404 BING XU, ADRIAN VAN RIXTEL and MICHIEL VAN LEUVENSTEIJN: Measuring bank competition in China: a comparison of new versus conventional approaches applied to loan markets.

1405 MIGUEL GARCÍA-POSADA and JUAN S. MORA-SANGUINETTI: Entrepreneurship and enforcement institutions: disaggregated evidence for Spain.

1406 MARIYA HAKE, FERNANDO LÓPEZ-VICENTE and LUIS MOLINA: Do the drivers of loan dollarisation differ between CESEE and Latin America? A meta-analysis.

1407 JOSÉ MANUEL MONTERO and ALBERTO URTASUN: Price-cost mark-ups in the Spanish economy: a microeconomic perspective.

1408 FRANCISCO DE CASTRO, FRANCISCO MARTÍ, ANTONIO MONTESINOS, JAVIER J. PÉREZ and A. JESÚS SÁNCHEZ-FUENTES: Fiscal policies in Spain: main stylised facts revisited.

1409 MARÍA J. NIETO: Third-country relations in the Directive establishing a framework for the recovery and resolution of credit institutions.

1410 ÓSCAR ARCE and SERGIO MAYORDOMO: Short-sale constraints and financial stability: evidence from the Spanish market.

1411 RODOLFO G. CAMPOS and ILIANA REGGIO: Consumption in the shadow of unemployment.

1412 PAUL EHLING and DAVID HAUSHALTER: When does cash matter? Evidence for private firms.

1413 PAUL EHLING and CHRISTIAN HEYERDAHL-LARSEN: Correlations.

1414 IRINA BALTEANU and AITOR ERCE: Banking crises and sovereign defaults in emerging markets: exploring the links.

1415 ÁNGEL ESTRADA, DANIEL GARROTE, EVA VALDEOLIVAS and JAVIER VALLÉS: Household debt and uncertainty: private consumption after the Great Recession.

1416 DIEGO J. PEDREGAL, JAVIER J. PÉREZ and A. JESÚS SÁNCHEZ-FUENTES: A toolkit to strengthen government budget surveillance.

1417 J. IGNACIO CONDE-RUIZ, and CLARA I. GONZÁLEZ: From Bismarck to Beveridge: the other pension reform in Spain.

1418 PABLO HERNÁNDEZ DE COS, GERRIT B. KOESTER, ENRIQUE MORAL-BENITO and CHRISTIANE NICKEL: Signalling fiscal stress in the euro area: a country-specific early warning system.

1419 MIGUEL ALMUNIA and DAVID LÓPEZ-RODRÍGUEZ: Heterogeneous responses to effective tax enforcement: evidence from Spanish firms.

1420 ALFONSO R. SÁNCHEZ: The automatic adjustment of pension expenditures in Spain: an evaluation of the 2013 pension reform

1421 JAVIER ANDRÉS, ÓSCAR ARCE and CARLOS THOMAS: Structural reforms in a debt overhang.

1422 LAURA HOSPIDO and ENRIQUE MORAL-BENITO: The public sector wage premium in Spain: evidence from longitudinal administrative data.

1423 MARÍA DOLORES GADEA-RIVAS, ANA GÓMEZ-LOSCOS and GABRIEL PÉREZ-QUIRÓS: The Two Greatest. Great Recession vs. Great Moderation.

1424 ENRIQUE MORAL-BENITO and OLIVER ROEHN: The impact of financial (de)regulation on current account balances.

1425 MAXIMO CAMACHO and JAIME MARTINEZ-MARTIN: Real-time forecasting US GDP from small-scale factor models.

1426 ALFREDO MARTÍN OLIVER, SONIA RUANO PARDO and VICENTE SALAS FUMÁS: Productivity and welfare: an application to the Spanish banking industry.

1427 JAVIER ANDRÉS and PABLO BURRIEL: Inflation dynamics in a model with firm entry and (some) heterogeneity.

1428 CARMEN BROTO and LUIS MOLINA: Sovereign ratings and their asymmetric response to fundamentals.

1429 JUAN ÁNGEL GARCÍA and RICARDO GIMENO: Flight-to-liquidity flows in the euro area sovereign debt crisis.

1430 ANDRĖ LEMELIN, FERNANDO RUBIERA-MOROLLÓN and ANA GÓMEZ-LOSCOS: Measuring urban agglomeration. A refoundation of the mean city-population size index.

1431 LUIS DIEEZ-CATALÁN and ERNESTO VILLANUEVA: Contract staggering and unemployment during the Great Recession: evidence from Spain. 
1501 LAURA HOSPIDO and EVA MORENO-GALBIS: The Spanish productivity puzzle in the Great Recession.

1502 LAURA HOSPIDO, ERNESTO VILLANUEVA and GEMA ZAMARRO: Finance for all: the impact of financial literacy training in compulsory secondary education in Spain.

1503 MARIO IZQUIERDO, JUAN F. JIMENO and AITOR LACUESTA: Spain: from immigration to emigration?

1504 PAULINO FONT, MARIO IZQUIERDO and SERGIO PUENTE: Real wage responsiveness to unemployment in Spain: asymmetries along the business cycle.

1505 JUAN S. MORA-SANGUINETTI and NUNO GAROUPA: Litigation in Spain 2001-2010: Exploring the market for legal services.

1506 ANDRES ALMAZAN, ALFREDO MARTÍN-OLIVER and JESÚS SAURINA: Securitization and banks' capital structure.

1507 JUAN F. JIMENO, MARTA MARTÍNEZ-MATUTE and JUAN S. MORA-SANGUINEITI: Employment protection legislation and labor court activity in Spain.

1508 JOAN PAREDES, JAVIER J. PÉREZ and GABRIEL PEREZ-QUIRÓS: Fiscal targets. A guide to forecasters?

1509 MAXIMO CAMACHO and JAIME MARTINEZ-MARTIN: Monitoring the world business cycle.

1510 JAVIER MENCÍA and ENRIQUE SENTANA: Volatility-related exchange traded assets: an econometric investigation.

1511 PATRICIA GÓMEZ-GONZÁLEZ: Financial innovation in sovereign borrowing and public provision of liquidity.

1512 MIGUEL GARCÍA-POSADA and MARCOS MARCHETTI: The bank lending channel of unconventional monetary policy: the impact of the VLTROs on credit supply in Spain.

1513 JUAN DE LUCIO, RAÚL MÍNGUEZ, ASIER MINONDO and FRANCISCO REQUENA: Networks and the dynamics of firms' export portfolio.

\begin{tabular}{|r|c|}
\hline BANCODEESPAÑ & $\begin{array}{c}\text { Unidad de Servicios Auxiliares } \\
\text { Alcalá, } 48-28014 \text { Madrid } \\
\text { E-mail: publicaciones@bde.es } \\
\text { www.bde.es }\end{array}$ \\
\hline
\end{tabular}

